\title{
On the contribution of nocturnal heterogeneous reactive nitrogen chemistry to particulate matter formation during wintertime pollution events in Northern Utah
}

\author{
Erin E. McDuffie ${ }^{1,2,3, a}$, Caroline C. Womack ${ }^{1,2}$, Dorothy L. Fibiger ${ }^{1,2, b}$, William P. Dube ${ }^{1,2}$, Alessandro Franchin ${ }^{1,2}$, \\ Ann M. Middlebrook ${ }^{1}$, Lexie Goldberger ${ }^{4, c}$, Ben H. Lee ${ }^{4}$, Joel A. Thornton ${ }^{4}$, Alexander Moravek ${ }^{5, d}$, \\ Jennifer G. Murphy ${ }^{5}$, Munkhbayar Baasandorj ${ }^{6, e}$, and Steven S. Brown ${ }^{1,3}$ \\ ${ }^{1}$ Chemical Sciences Division, National Oceanic and Atmospheric Administration, Boulder, CO, USA \\ ${ }^{2}$ Cooperative Institute for Research in Environmental Sciences, University of Colorado, Boulder, CO, USA \\ ${ }^{3}$ Department of Chemistry, University of Colorado, Boulder, CO, USA \\ ${ }^{4}$ Department of Atmospheric Science, University of Washington, Seattle, WA, USA \\ ${ }^{5}$ Department of Chemistry, University of Toronto, Toronto, ON, Canada \\ ${ }^{6}$ Department of Atmospheric Sciences, University of Utah, Salt Lake City, UT, USA \\ ${ }^{a}$ now at: Department of Physics and Atmospheric Science, Dalhousie University, Halifax, NS, Canada \\ bnow at: California Air Resources Board, Sacramento, CA, USA \\ ${ }^{c}$ now at: ARM Aerial Facility, Pacific Northwest National Laboratory, Richland, WA, USA \\ ${ }^{d}$ now at: Department of Chemistry, York University, Toronto, ON, Canada \\ enow at: Chevron Corporation, Houston, TX, USA
}

Correspondence: Steven S. Brown (steven.s.brown@noaa.gov)

Received: 1 March 2019 - Discussion started: 15 March 2019

Revised: 16 June 2019 - Accepted: 27 June 2019 - Published: 19 July 2019

\begin{abstract}
Mountain basins in Northern Utah, including the Salt Lake Valley (SLV), suffer from wintertime air pollution events associated with stagnant atmospheric conditions. During these events, fine particulate matter concentrations $\left(\mathrm{PM}_{2.5}\right)$ can exceed national ambient air quality standards. Previous studies in the SLV have found that $\mathrm{PM}_{2.5}$ is primarily composed of ammonium nitrate $\left(\mathrm{NH}_{4} \mathrm{NO}_{3}\right)$, formed from the condensation of gas-phase ammonia $\left(\mathrm{NH}_{3}\right)$ and nitric acid $\left(\mathrm{HNO}_{3}\right)$. Additional studies in several western basins, including the SLV, have suggested that production of $\mathrm{HNO}_{3}$ from nocturnal heterogeneous $\mathrm{N}_{2} \mathrm{O}_{5}$ uptake is the dominant source of $\mathrm{NH}_{4} \mathrm{NO}_{3}$ during winter. The rate of this process, however, remains poorly quantified, in part due to limited vertical measurements above the surface, where this chemistry is most active. The 2017 Utah Winter Fine Particulate Study (UWFPS) provided the first aircraft measurements of detailed chemical composition during wintertime pollution events in the SLV. Coupled with ground-based observations, analyses of day- and nighttime research flights confirm that $\mathrm{PM}_{2.5}$ during wintertime pollution events is prin-
\end{abstract}

cipally composed of $\mathrm{NH}_{4} \mathrm{NO}_{3}$, limited by $\mathrm{HNO}_{3}$. Here, observations and box model analyses assess the contribution of $\mathrm{N}_{2} \mathrm{O}_{5}$ uptake to nitrate aerosol during pollution events using the $\mathrm{NO}_{3}^{-}$production rate, $\mathrm{N}_{2} \mathrm{O}_{5}$ heterogeneous uptake coefficient $\left(\gamma\left(\mathrm{N}_{2} \mathrm{O}_{5}\right)\right)$, and production yield of $\mathrm{ClNO}_{2}$ $\left(\varphi\left(\mathrm{ClNO}_{2}\right)\right)$, which had medians of $1.6 \mu \mathrm{g} \mathrm{m}^{-3} \mathrm{~h}^{-1}, 0.076$, and 0.220 , respectively. While fit values of $\gamma\left(\mathrm{N}_{2} \mathrm{O}_{5}\right)$ may be biased high by a potential under-measurement in aerosol surface area, other fit quantities are unaffected. Lastly, additional model simulations suggest nocturnal $\mathrm{N}_{2} \mathrm{O}_{5}$ uptake produces between 2.4 and $3.9 \mu \mathrm{g} \mathrm{m}^{-3}$ of nitrate per day when considering the possible effects of dilution. This nocturnal production is sufficient to account for $52 \%-85 \%$ of the daily observed surface-level buildup of aerosol nitrate, though accurate quantification is dependent on modeled dilution, mixing processes, and photochemistry. 


\section{Introduction}

Over $80 \%$ of Utah's population lives in counties that experience periods of elevated fine particulate matter $\left(\mathrm{PM}_{2.5}<2.5 \mu \mathrm{m}\right.$ in diameter) during the winter season (U.S. Census Bureau, 2018; Whiteman et al., 2014). In these counties, the highest levels have been limited to three northern valleys along the Wasatch Mountains, shown in Fig. 1 (north to south: Cache Valley (Logan nonattainment area, NAA), Salt Lake Valley (Salt Lake NAA), and Utah Valley (Provo NAA)). These valleys were designated by the United States Environmental Protection Agency (EPA) as "moderate" nonattainment areas (NAA) in December 2009, with the Salt Lake and Provo areas reclassified from moderate to "serious" in May 2017 (Utah Department of Environmental Quality, 2019). Elevated $\mathrm{PM}_{2.5}$ concentrations in these regions impact public health and are associated with increases in emergency room visits for asthma (Beard et al., 2012). Short-term exposure to $\mathrm{PM}_{2.5}$ has also been shown to increase the chance of triggering acute ischemic heart disease events by $4.5 \%-6 \%$ per $10 \mu \mathrm{g} \mathrm{m}^{-3}$ in sensitive populations living in the Wasatch region (Pope et al., 2006, 2015).

Elevated wintertime $\mathrm{PM}_{2.5}$ concentrations in these valleys typically correspond to multiday events of high atmospheric stability (e.g., Whiteman et al., 2014; Silcox et al., 2012; Gillies et al., 2010; Wang et al., 2012; Green et al., 2015; Silva et al., 2007; Baasandorj et al., 2017), associated with large, synoptic-scale high-pressure systems that transit from west to east, simultaneously impacting multiple basins across the intermountain western US (e.g., Reeves and Stensrud, 2009). Warm temperatures aloft cause boundary layer stratification that reduces mixing and traps cold air and emissions near the surface, illustrated in Fig. 2 and discussed further below. These events, termed persistent cold air pools (PCAPs), typically mix out after $1-5 \mathrm{~d}$ but have been observed to persist for as long as $18 \mathrm{~d}$ (Whiteman et al., 2014). Similar meteorological patterns have been linked to wintertime $\mathrm{PM}_{2.5}$ accumulation in basins across the western US (e.g., Chen et al., 2012; Green et al., 2015). During past PCAP and pollution events in Utah, data from ground-based measurements in the Salt Lake Valley (SLV) have reported day-to-day buildup rates of total $\mathrm{PM}_{2.5}$ mass in the range of $\sim 6-10 \mu \mathrm{g} \mathrm{m}^{-3} \mathrm{~d}^{-1}$ (Baasandorj et al., 2017; Silcox et al., 2012; Whiteman et al., 2014) before plateauing after $\sim 6 \mathrm{~d}$ into an event (Baasandorj et al., 2017). Average $24 \mathrm{~h}$ concentrations reported during PCAP events between 2001 and 2016 have been as large as $40-80 \mu \mathrm{g} \mathrm{m}^{-3}$ in Salt Lake (Baasandorj et al., 2017; Silcox et al., 2012) and Utah valleys (Malek et al., 2006) and up to $132.5 \mu \mathrm{g} \mathrm{m}^{-3}$ in Logan, Utah (Cache Valley) (Malek et al., 2006).

Previous ground-based studies have identified ammonium nitrate $\left(\mathrm{NH}_{4} \mathrm{NO}_{3}\right)$ as the main component of $\mathrm{PM}_{2.5}(70 \%-$ $80 \%$ by mass) during PCAP events in all three Northern Utah valleys (Silva et al., 2007; Hansen et al., 2010; Kuprov et al., 2014; Kelly et al., 2013; Long et al., 2003, 2005a, b; Baasandorj et al., 2017). Ammonium nitrate formation is thermodynamically favorable under cold wintertime conditions from the equilibrium between gas-phase ammonia $\left(\mathrm{NH}_{3}\right)$ and nitric acid $\left(\mathrm{HNO}_{3}\right)$, shown in Reaction (R1) in Fig. 2 (e.g., Kuprov et al., 2014; Nowak et al., 2012; Mozurkewich, 1993). $\mathrm{PM}_{2.5}$ mitigation strategies that are based on control of these gas-phase species are expected to be more effective if the limiting reagent and its sources can be identified. Both observationally and model-informed ground-based analyses have suggested that $\mathrm{NH}_{4} \mathrm{NO}_{3}$ formation in Cache and Salt Lake valleys is limited by the production of $\mathrm{HNO}_{3}$ (Kuprov et al., 2014; Mangelson et al., 1997; Martin, 2006; Utah Division of Air Quality, 2014a, b, c; Franchin et al., 2018), though uncertainties remain in how this limitation may be impacted by temporal and spatial variations.

While $\mathrm{NH}_{3}$ is directly emitted from agricultural sources, industrial processes, waste disposal, and automobile emissions (Behera et al., 2013; Livingston et al., 2009), $\mathrm{HNO}_{3}$ forms chemically in the atmosphere from the oxidation of $\mathrm{NO}_{x}\left(=\mathrm{NO}+\mathrm{NO}_{2}\right)$, which in turn arises mainly from combustion emissions. There are two mechanisms by which this formation occurs, illustrated by Reactions (R2)-(R6) in Fig. 2. The first is through daytime $\mathrm{NO}_{2}$ oxidation by the hydroxyl radical $(\mathrm{OH})$ (Fig. 2, Reaction R2) and the second is through the nocturnal heterogeneous uptake of dinitrogen pentoxide $\left(\mathrm{N}_{2} \mathrm{O}_{5}\right)$ (Reaction R6), which itself is a product of nocturnal $\mathrm{NO}_{x}$ oxidation (Reactions $\mathrm{R} 3-\mathrm{R} 5$ ). The former is relatively more important during the summer (Brown et al., 2004), whereas the latter, the focus of this study, may be relatively more important in winter (e.g., Wagner et al., 2013) due to reduced $\mathrm{OH}$ concentrations, colder temperatures that favor $\mathrm{N}_{2} \mathrm{O}_{5}$ in its equilibrium with $\mathrm{NO}_{3}$ (Reaction R5), and longer nights that allow more time for nocturnal reactions to occur. The nocturnal heterogeneous production of $\mathrm{HNO}_{3}$ is also expected to be largest in the residual layer (RL), due to the near-surface accumulation of $\mathrm{NO}$, which titrates $\mathrm{O}_{3}$ (Reaction R3) and reacts with $\mathrm{NO}_{3}$ (Reaction R7), the precursor to $\mathrm{N}_{2} \mathrm{O}_{5}$ (e.g., Brown and Stutz, 2012).

The role of this nocturnal reactive nitrogen chemistry in the formation of $\mathrm{PM}_{2.5}$ has been considered in previous wintertime studies, though nocturnal, vertically resolved measurements have been relatively limited. Previous studies using ground- and tower-based observations, as well as midmorning aircraft vertical profiles, have identified heterogeneous chemistry and subsequent morning transport from aloft as a major source of surface-level $\mathrm{NH}_{4} \mathrm{NO}_{3}$ in California's San Joaquin Valley (e.g., Brown et al., 2006; Prabhakar et al., 2017; Pusede et al., 2016; Watson and Chow, 2002). Similarly, a box model analysis of tower- and groundbased observations in Beijing, China, also identified these processes as important contributors to surface-level particulate nitrate the following day (Wang et al., 2018). In Northern Utah specifically, nocturnal heterogeneous chemistry has been considered a source for $\mathrm{PM}_{2.5}$ (Baasandorj et al., 2017; 


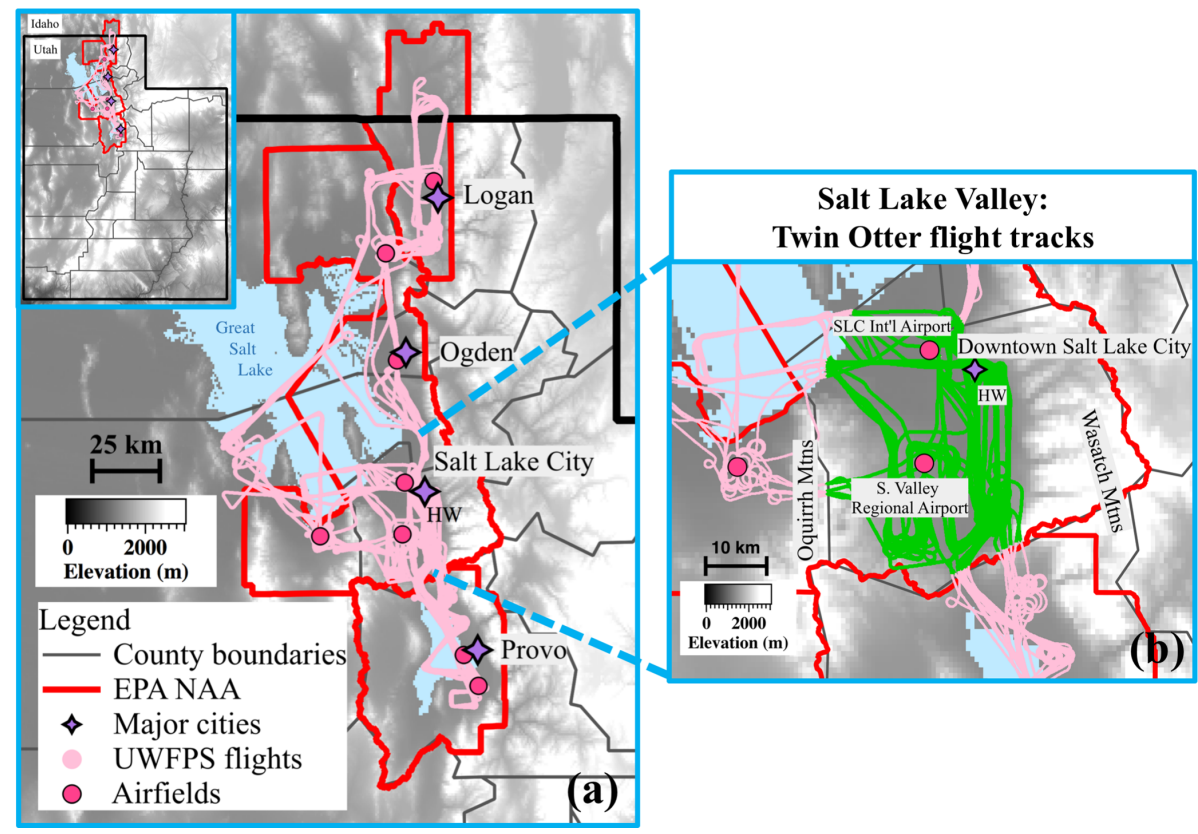

Figure 1. (a) Elevation map of Utah's Wasatch region (Utah State in insert), with the Great Salt Lake (north) and Utah Lake (south) shown in blue and county borders in gray. The US-EPA-designated nonattainment areas (NAA) for $\mathrm{PM}_{2.5}$ are shown by red boundaries. From north to south these NAAs include the Logan NAA: moderate status, Salt Lake City NAA: serious status, and Provo NAA: serious status. UWFPS Twin Otter flight tracks are shown in pink. Purple markers indicate the locations of major cities, including Logan in the Cache Valley, Ogden and Salt Lake City in the SLV, and Provo in the Utah Valley. The locations of missed approaches conducted with the aircraft are shown by dark pink circles. The Hawthorne (HW) measurement site in the SLV is labeled. (b) Expanded view of the SLV, with analyzed flight tracks highlighted in green.

Kuprov et al., 2014), though vertically resolved measurements have been limited to ground-based observations at different elevations along the Wasatch Mountains (Baasandorj et al., 2017). In an analysis of ground-based $\mathrm{HNO}_{3}$ and $\mathrm{PM}_{2.5}$ observations in the SLV, Kuprov et al. (2014) suggested that daytime $\mathrm{HNO}_{3}$ formation was dominant over the contribution from nocturnal heterogeneous chemistry. Baasandorj et al. (2017), however, noted that ground-based measurements in this region may not capture the extent of heterogeneous chemistry aloft in the RL, which is expected to be distinct from the surface composition (e.g., Brown et al., 2007; Brown and Stutz, 2012; Stutz et al., 2004). Therefore, vertical gradients in $\mathrm{NO}_{x}$ and oxidants could promote efficient $\mathrm{HNO}_{3}$ and $\mathrm{NH}_{4} \mathrm{NO}_{3}$ formation aloft, which could contribute to enhanced surface-level $\mathrm{PM}_{2.5}$ concentrations the following day. Regardless of altitude, the absolute contribution at all altitudes will depend on (1) the rate of $\mathrm{NO}_{3}$ and $\mathrm{N}_{2} \mathrm{O}_{5}$ production, (2) the efficiency of $\mathrm{N}_{2} \mathrm{O}_{5}$ uptake onto aerosol $\left(\gamma\left(\mathrm{N}_{2} \mathrm{O}_{5}\right)\right)$, and (3) the heterogeneous production yield of $\mathrm{HNO}_{3}$ relative to $\mathrm{ClNO}_{2}\left(\varphi\left(\mathrm{ClNO}_{2}\right)\right)$ (Osthoff et al., 2008; Behnke et al., 1997). Net accumulation of $\mathrm{NH}_{4} \mathrm{NO}_{3}$ at the surface, however, also depends on mixing and dilution associated with growth of the convective boundary layer and mixing of the RL down to the surface the following day. Quantification of these processes is key in designing effective mitigation strategies for Utah's wintertime air pollution and requires vertically resolved observations of chemical composition at night.

In this study, we present results from the Utah Winter Fine Particulate Study (UWFPS), which consisted of aircraft and ground-based observations throughout the Cache, Salt Lake, and Utah valleys during January and February 2017. This analysis focuses on data from 16 aircraft flights (5 at night) during two pollution events between 16 January and 1 February 2017. These flights were carried out in the SLV, the most populated of the three Utah nonattainment areas. The first section presents an overview of $\mathrm{PM}_{2.5}$ during winter 2016-2017. In the second section, ambient mixing ratios of total (gas and particle phase) oxidized and reduced nitrogen are used to identify the limiting reagent to $\mathrm{NH}_{4} \mathrm{NO}_{3}$ aerosol formation, as well as its spatial and temporal trends. The final section presents upper-limit $\mathrm{NH}_{4} \mathrm{NO}_{3}$ production rate estimates and results from an observationally fit chemical box model to calculate $\gamma\left(\mathrm{N}_{2} \mathrm{O}_{5}\right), \varphi\left(\mathrm{ClNO}_{2}\right)$, and an estimated contribution of nocturnal heterogeneous chemistry to $\mathrm{NH}_{4} \mathrm{NO}_{3}$ formation in the SLV. The contribution of nocturnal production relative to photochemically driven $\mathrm{NO}_{2}$ oxidation will have consequences for the development of effective mitigation strategies as day- and nighttime production processes may have different sensitivities to $\mathrm{NO}_{x}$ emissions and VOC 


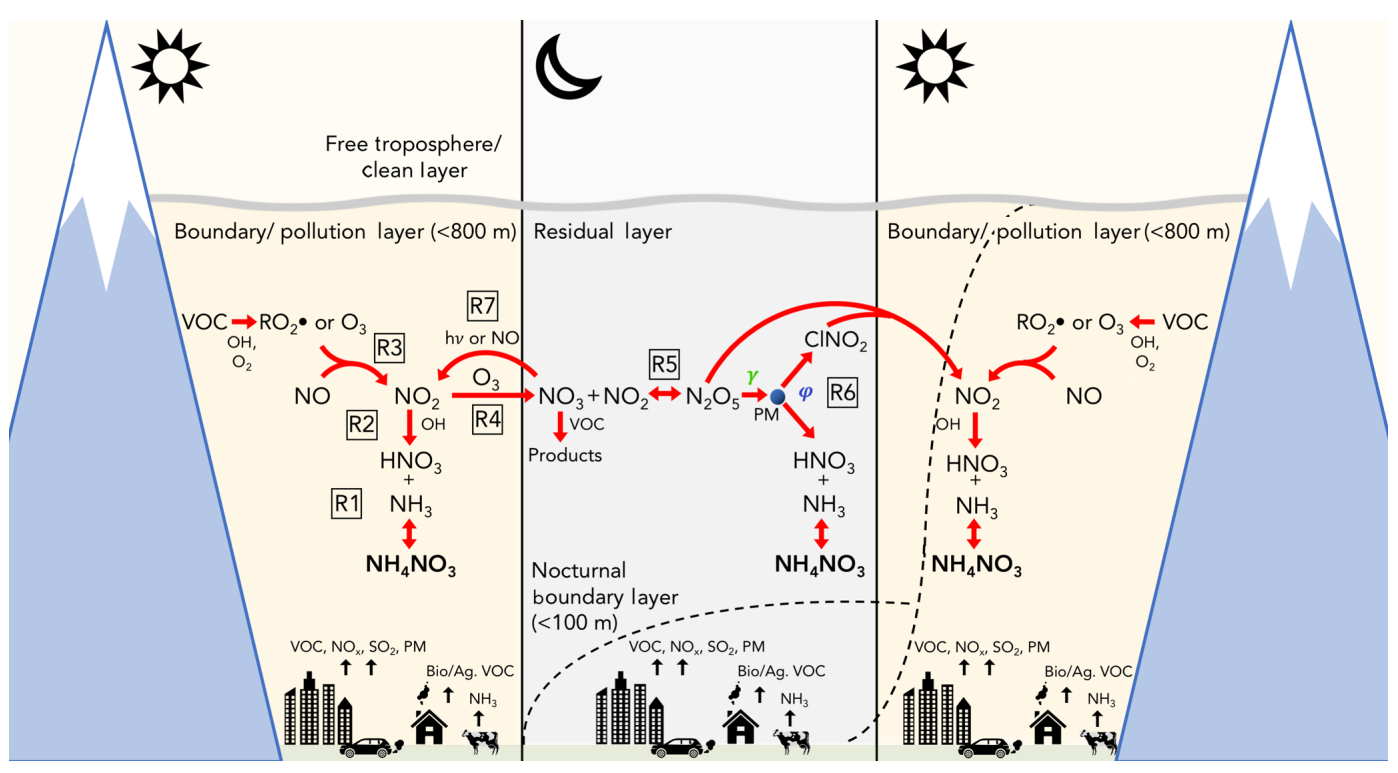

Figure 2. Illustration of the day-night dynamics and chemical cycles of reactive nitrogen oxides, $\mathrm{O}_{3}$, and $\mathrm{NH}_{4} \mathrm{NO}_{3}$ during $\mathrm{PCAP}$ conditions in the SLV. The development of the nocturnal boundary layer and morning growth and mix-out are illustrated by the dashed lines. Figure is not to scale. Reaction (R6) represents the reaction $\mathrm{N}_{2} \mathrm{O}_{5} \stackrel{\gamma\left(\mathrm{N}_{2} \mathrm{O}_{5}\right)}{\longrightarrow}, M$

radical sources (Pusede et al., 2016; Womack et al., 2019), such that net sensitivities will be determined by the dominant formation mechanism.

\section{Methods}

\subsection{UWFPS campaign overview and instrumentation}

The UWFPS campaign included both aircraft and groundbased measurements throughout the Salt Lake, Cache, and Utah valleys during January and February 2017 (Fig. 1). A total of 23 research flights were conducted during both day and night with the NOAA Twin Otter (TO) aircraft. The TO was equipped with aerosol- and gas-phase instrumentation (summarized in Table 1) to probe the regional sources and formation mechanisms of $\mathrm{PM}_{2.5}$. While flights were conducted over three valleys, the focus of this analysis will be on the more densely populated SLV, with relevant flight tracks highlighted in the right panel of Fig. 1.

Briefly, the TO payload included gas-phase measurements of $\mathrm{NO}_{x}, \mathrm{NO}_{2}, \mathrm{NO}_{y}$, and $\mathrm{O}_{3}(1 \mathrm{~Hz}$ sample frequency) from a NOAA cavity ring-down spectrometer (NOxCaRD) (Wild et al., 2014); $\mathrm{NH}_{3}$ (1 Hz sample frequency) measurements from an Aerodyne midinfrared absorption instrument (QCTILDAS) from the University of Toronto (Ellis et al., 2010); and $\mathrm{N}_{2} \mathrm{O}_{5}, \mathrm{HNO}_{3}$, and $\mathrm{ClNO}_{2}$ (1 Hz sample frequency) measurements from an iodide time-of-flight chemical ionization mass spectrometer ( ${ }^{-}$ToF-CIMS) from the University of Washington (Lee et al., 2014, 2018). Accuracies for $\mathrm{NO}_{x}$, $\mathrm{NO}_{2}$, and $\mathrm{O}_{3}$ were $5 \%$ and $12 \%$ for $\mathrm{NO}_{y}$, with stated detec- tion limits of $60 \mathrm{pptv}(2 \sigma)$ (Wagner et al., 2011; Wild et al., 2014) in the boundary layer. Gas-phase $\mathrm{NH}_{3}$ was measured with a detection limit of $450 \mathrm{pptv}(1 \mathrm{~s} 3 \sigma)$, as described in further detail by Moravek et al. (2019). Accuracy and detection limits for $\mathrm{N}_{2} \mathrm{O}_{5}, \mathrm{ClNO}_{2}$, and $\mathrm{HNO}_{3}$ were similar to those reported from the same instrument deployed during the Wintertime Investigation of Transport, Emissions, and Reactivity (WINTER) campaign ( $\leq 0.6$ pptv $(1 \mathrm{~s} 1 \sigma), 30 \%)$ (Lee et al., 2018). Non-refractory submicron aerosol composition (sampled every $\sim 10 \mathrm{~s}$ ) was measured with the NOAA aerosol mass spectrometer (AMS) (Bahreini et al., 2009; Middlebrook et al., 2012) and aerosol size (sample every $\sim 3 \mathrm{~s}$ ) with a commercial ultra-high-sensitivity aerosol spectrometer (UHSAS) (Brock et al., 2011). Average detection limits for AMS aerosol composition were 0.04, 0.09, 0.33, 0.03, and $0.07 \mu \mathrm{g} \mathrm{sm}^{-3}\left(\mathrm{sm}^{-3}\right.$ refers to $\mathrm{m}^{3}$ under standard conditions: $1 \mathrm{~atm}$ and $273.15 \mathrm{~K}$ ) for particulate nitrate, ammonium, organics, sulfate, and chloride, respectively. Uncertainties were $\sim 20 \%$ for all species (Franchin et al., 2018). Ambient temperature and pressure (1 Hz sample frequency) were measured with a commercial (Avantech) meteorological probe. The accuracy of the commercial UHSAS instrument was also expected to be similar to that used during WINTER (dry surface area density: $~ 34 \%$ ).

Additional ground-based measurements used in this analysis include hourly $\mathrm{PM}_{2.5}, \mathrm{NO}_{2}, \mathrm{O}_{3}$, and temperature from the Utah Department of Air Quality (UDAQ) instrumentation at the Hawthorne (HW) monitoring site (Fig. 1). Total $\mathrm{PM}_{2.5}$ mass was measured with a Thermo Scientific 1405DF dichotomous ambient air monitor, $\mathrm{NO}_{2}$ with a Teledyne API T200U chemiluminescence detector, and $\mathrm{O}_{3}$ with 
Table 1. Aircraft measurements used in this analysis.

\begin{tabular}{llrrll}
\hline Compound & Method/instrument & Accuracy & Meas. frequency & Location & Reference \\
\hline Gas-phase species & & & & & \\
\hline $\mathrm{NO}$ & CRDS $^{\mathrm{a}}$ & $5 \%$ & $1 \mathrm{~s}$ & Aircraft & Fuchs et al. (2009); Wild et al. (2014) \\
$\mathrm{NO}_{2}$ & $\mathrm{CRDS}$ & $5 \%$ & $1 \mathrm{~s}$ & Aircraft & Fuchs et al. (2009); Wild et al. (2014) \\
$\mathrm{O}_{3}$ & $\mathrm{CRDS}$ & $5 \%$ & $1 \mathrm{~s}$ & Aircraft & Washenfelder et al. (2011); Wild et al. (2014) \\
$\mathrm{NO}_{y}$ & CRDS & $12 \%$ & $1 \mathrm{~s}$ & Aircraft & Wild et al. (2014) \\
$\mathrm{N}_{2} \mathrm{O}_{5}$ & $\mathrm{I}^{-}$ToF-CIMS & $30 \%$ & $1 \mathrm{~s}$ & Aircraft & Lee et al. (2014) \\
$\mathrm{ClNO}_{2}$ & $\mathrm{I}^{-}$ToF-CIMS & $30 \%$ & $1 \mathrm{~s}$ & Aircraft & Lee et al. (2014) \\
$\mathrm{NH}_{3}$ & QC-TILDAS $^{\mathrm{d}}$ & & $1 \mathrm{~s}$ & Aircraft & Ellis et al. (2010) \\
\hline Aerosol measurements & & & & \\
\hline $\begin{array}{l}\text { Aerosol }(<1 \mu \mathrm{m}) \\
\text { Composition }\end{array}$ & AMS & $20 \%$ & $10 \mathrm{~s}$ & Aircraft & Bahreini et al. (2009); Middlebrook et al. (2012) \\
$\begin{array}{l}\text { Dry surface area } \\
\text { Density }(<1 \mu \mathrm{m})\end{array}$ & $\mathrm{UHSAS}^{\mathrm{f}}$ & & & & \\
\hline
\end{tabular}

${ }^{a}$ NOAA, cavity ring-down spectrometer (CRDS, NOxCaRD). ${ }^{b}$ Hawthorne. ${ }^{c}$ University of Washington, iodide time-of-flight chemical ionization mass spectrometer. ${ }^{d}$ University

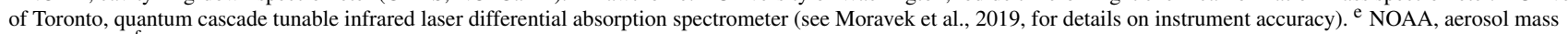
spectrometer. ${ }^{\mathrm{f}}$ Droplet Measurement Techniques, ultra-high-sensitivity aerosol spectrometer. ${ }^{\mathrm{g}}$ Estimated according to the performance of a different UHSAS in the WINTER campaign.

a Teledyne API T400 UV absorption spectrometer, all in accordance with EPA guidelines (Environmental Protection Agency, 2018). Select volatile organic compounds (VOCs) were also measured at the University of Utah (UU) ground site by a proton-transfer-reaction mass spectrometer. Further information about the UWFPS campaign and aircraft and ground-based instrumentation can be found in additional publications (Franchin et al., 2018; UWFPS Science Team, 2018; Womack et al., 2019; Moravek et al., 2019).

\subsection{Box model}

\subsubsection{Description}

A zero-dimension chemical box model has been developed to simulate the nocturnal chemical evolution of an air parcel from sunset until the time of aircraft measurement (assuming constant temperature and relative humidity). Extensive model details have been previously discussed in McDuffie et al. (2018b). Briefly, the model forward integrates the chemical mechanism (13 reactions, Table S1 in the Supplement) starting $1.3 \mathrm{~h}$ prior to sunset (see below), iteratively adjusting the initial concentrations of $\mathrm{O}_{3}$ and $\mathrm{NO}_{2}$ until the modelpredicted concentrations are both within $0.5 \%$ of the aircraft observations. Holding these initial concentrations constant, the model next adjusts the total heterogeneous loss rate constant of $\mathrm{N}_{2} \mathrm{O}_{5}\left(k_{\mathrm{N}_{2} \mathrm{O}_{5}}\right)$ until the model output reproduces ambient nighttime observations of $\mathrm{N}_{2} \mathrm{O}_{5}$ to within $1 \%$. As described in McDuffie et al. (2018b), the model iterates these steps, readjusting initial concentrations of $\mathrm{O}_{3}$ and $\mathrm{NO}_{2}$ and values of $k_{\mathrm{N}_{2} \mathrm{O}_{5}}$ until aircraft observations of $\mathrm{NO}_{2}, \mathrm{O}_{3}$, and $\mathrm{N}_{2} \mathrm{O}_{5}$ are simultaneously reproduced by the model. The final step holds these values constant while iteratively adjusting the production rate of $\mathrm{ClNO}_{2}\left(k_{\mathrm{ClNO}_{2}}\right)$ until the modeled mixing ratios of $\mathrm{ClNO}_{2}$ are within $1 \%$ of the nighttime $\mathrm{ClNO}_{2}$ observations. The $\mathrm{N}_{2} \mathrm{O}_{5}$ uptake coefficients $\left(\gamma\left(\mathrm{N}_{2} \mathrm{O}_{5}\right)\right)$ and $\mathrm{ClNO}_{2}$ production yields $\left(\varphi\left(\mathrm{ClNO}_{2}\right)\right)$ are then calculated following Eqs. (1) and (2), where $c$ is the mean molecular speed and $\mathrm{SA}$ is the ambient wet $\mathrm{PM}_{1}$ surface area density (described below). The model repeats this entire process every $10 \mathrm{~s}$ for all flights conducted at night, as determined by time and aircraft GPS altitude.

$\gamma\left(\mathrm{N}_{2} \mathrm{O}_{5}\right)=\frac{4 \cdot k_{\mathrm{N}_{2} \mathrm{O}_{5}}}{c \cdot \mathrm{SA}}$
$\varphi\left(\mathrm{ClNO}_{2}\right)=\frac{k_{\mathrm{ClNO}_{2}}}{k_{\mathrm{N}_{2} \mathrm{O}_{5}}}$

Holding the derived $k_{\mathrm{N}_{2} \mathrm{O}_{5}}$ and $k_{\mathrm{ClNO}_{2}}$ values constant, the model can further simulate the total nitrate produced overnight by forward integrating the model until the time of sunrise, as shown for a representative SLV point in Fig. 3. Here, total nitrate (gas + particulate phase) is represented as $\mathrm{HNO}_{3}$ only, as this model does not include aerosol thermodynamics that partition nitrate between the gas and particle phases. Modeled gas-phase $\mathrm{HNO}_{3}$ is assumed to partition to the particle phase with $100 \%$ efficiency, following observations presented in Franchin et al. (2018) that show $>90 \%$ of total nitrate is in the particle phase during wintertime pollution events in the SLV. As modeled nitrate is initialized with a concentration of $0 \mu \mathrm{g} \mathrm{m}^{-3}$, concentrations predicted at sunrise represent the total amount of nitrate produced from nocturnal chemistry over the course of a single night (i.e., nocturnal nitrate production rate). These base case values assume no overnight loss from dilution and constant values of $\gamma\left(\mathrm{N}_{2} \mathrm{O}_{5}\right)$ and $\varphi\left(\mathrm{ClNO}_{2}\right)$, as discussed further in Sect. 3.3.3. 


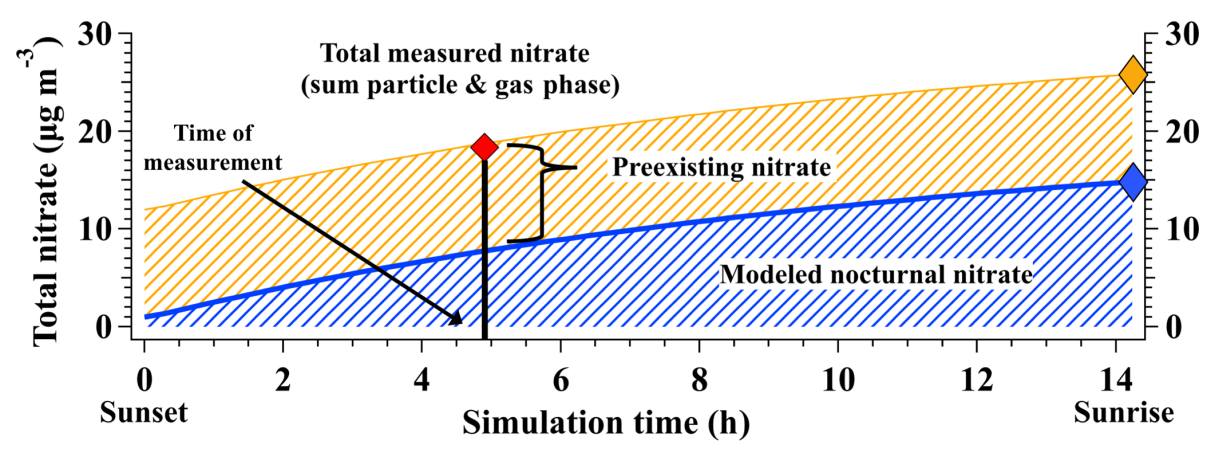

Figure 3. Example simulation of total nitrate production from sunset to sunrise for an air parcel sampled over the SLV on 28 January 2017. Model-derived $\gamma\left(\mathrm{N}_{2} \mathrm{O}_{5}\right)$ and $\varphi\left(\mathrm{ClNO}_{2}\right)$ values were 0.05 and 0.21 , respectively. Modeled nocturnal nitrate (blue) is the total nitrate produced by heterogeneous chemistry in the box model, with the nocturnal production rate $\left(\mu \mathrm{g} \mathrm{m}^{-3}\right.$ per night) represented by the blue diamond. Preexisting nitrate (yellow) represents the nitrate present at sunset and is calculated as the difference between total measured nitrate from the aircraft (red diamond) and the model-predicted nitrate at the time of aircraft measurement (vertical black line). Assuming preexisting nitrate is constant overnight (i.e., no deposition or dilution) and constant values of $\gamma\left(\mathrm{N}_{2} \mathrm{O}_{5}\right)$ and $\varphi\left(\mathrm{ClNO}_{2}\right)$, total nitrate expected at sunrise is represented by the gold diamond.

\subsubsection{Model simplifications and uncertainties}

For the UWFPS campaign, the box model was run in a similar manner to that described previously in McDuffie et al. (2018b), for nocturnal aircraft observations collected in the RL over the eastern US coast during the 2015 WINTER campaign. Due to more limited instrumentation during UWFPS than WINTER, a larger number of box model assumptions and simplifications were required, which are summarized below.

First, the wet SA density for the base case simulations was calculated by applying a hygroscopic growth curve as a function of RH (Fig. S2 in the Supplement) to the dry $\mathrm{PM}_{1} \mathrm{SA}$ measured by the UHSAS (details in Sect. S1.3 in the Supplement). The growth curve was derived with the Extended AIM Aerosol Thermodynamic Model (Wexler and Clegg, 2002), assuming pure $\mathrm{NH}_{4} \mathrm{NO}_{3}$ particles. Alternatively, estimating the growth factor from AMS measurements and estimates of aerosol organic density and the organic hygroscopicity constant $\left(\kappa_{\text {Org }}\right)$ (described in Sect. S1.3; Jimenez et al., 2009; Mei et al., 2013; Cerully et al., 2015; e.g., Kuwata et al., 2012; Brock et al., 2016; Shingler et al., 2016) resulted in only a $\sim 3 \%$ change in the total wet SA for night flights during UWFPS (Fig. S2). For the 1031 measurement periods $\left(10 \mathrm{~s}\right.$ each) with simultaneous values of $\gamma\left(\mathrm{N}_{2} \mathrm{O}_{5}\right)$ and $\varphi\left(\mathrm{ClNO}_{2}\right)$, the median dry aerosol SA was $151.9 \mu \mathrm{m}^{2} \mathrm{~cm}^{-3}$, which increased to $353.1 \mu^{2} \mathrm{~cm}^{-3}$ when accounting for hygroscopic growth (Fig. S2). Additional uncertainties associated with hygroscopic growth and assumptions of constant SA are discussed below in Sect. 3.3.2.

Second, loss of the nitrate radical $\left(\mathrm{NO}_{3}\right)$ from its reaction with volatile organic compounds (VOCs) was assumed to occur with a single first-order rate constant $\left(k_{\mathrm{NO}_{3}}\right)$, calculated for each flight from a combination of historical ground-based VOC measurements and select VOC measurements from a
PTR-MS at the UU site (see Sect. S1.2 for details; Atkinson and Arey, 2003). At night, $\mathrm{NO}_{3}$ serves as one of the primary tropospheric oxidants for VOCs and can react with $\mathrm{RO}_{2}$ and $\mathrm{HO}_{2}$ radicals to contribute to nocturnal $\mathrm{NO}_{x}$ recycling (Vaughan et al., 2006). In this analysis, $\mathrm{NO}_{3}-\mathrm{VOC}$ reactions were lumped and treated as a net $\mathrm{NO}_{x}$ sink with values of the first-order loss rate constant, $k_{\mathrm{NO}_{3}}$, ranging from $1.5 \times 10^{-3}$ to $9.5 \times 10^{-3} \mathrm{~s}^{-1}\left(\mathrm{NO}_{3}\right.$ lifetime $\left.\sim 100-1000 \mathrm{~s}\right)$. These rate constants are slightly larger than average values measured during the WINTER campaign $\left(1.3 \times 10^{-4}\right.$ to $\left.4.6 \times 10^{-4} \mathrm{~s}^{-1}\right)$ (McDuffie et al., 2018b) and within the range previously reported $\left(3 \times 10^{-5}\right.$ to $\left.1 \times 10^{-2} \mathrm{~s}^{-1}\right)$ during winter 2012 at a ground site in Colorado (Wagner et al., 2013). Additional $\mathrm{NO}_{x}$ regeneration from reactions of $\mathrm{NO}_{3}$ with $\mathrm{HO}_{2}$ and $\mathrm{RO}_{2}$ radicals was not included in this analysis due to a lack of radical measurements. An underprediction in $k_{\mathrm{NO}_{3}}$ from these uncertainties would cause both an overprediction in the loss rate constant of $\mathrm{N}_{2} \mathrm{O}_{5}$ and the subsequent production of nitrate. While uncertainties in $k_{\mathrm{NO}_{3}}$ can lead to large model uncertainties during summertime conditions (e.g., Phillips et al., 2016), $\mathrm{NO}_{3}-\mathrm{VOC}$ reactivity is largely reduced during the winter season as a result of lower biogenic emissions and colder temperatures that favor $\mathrm{N}_{2} \mathrm{O}_{5}$ in its equilibrium with $\mathrm{NO}_{3}$. Sensitivity studies discussed below showed $0.2 \%$ changes in the median model-predicted nocturnal nitrate production rate associated with $\pm 50 \%$ changes in $k_{\mathrm{NO}_{3}}$ (Table S4). The possibility of varying VOC reactivity with time was also investigated (Sect. S1.4.5) but resulted in a minimal $(<0.1 \%)$ impact on nitrate production results presented below. The potential for other rate constants to vary with time may additionally lead to increased variability in the results presented in Sect. 3.3.

Third, there are uncertainties in the assumptions regarding the start time and duration of each simulation. All simulations were initialized at $1.3 \mathrm{~h}$ prior to sunset, assuming 
no initial concentrations of $\mathrm{N}_{2} \mathrm{O}_{5}$ or $\mathrm{ClNO}_{2}$. The presunset time of $1.3 \mathrm{~h}$ was derived for the WINTER campaign, based on the time when predicted daytime $\mathrm{N}_{2} \mathrm{O}_{5}$ concentrations (described in Sect. S1.4.4 and Brown et al., 2005) diverged from ambient observations when approaching sunset. This value was not recalculated for UWFPS simulations as daytime $\mathrm{N}_{2} \mathrm{O}_{5}$ calculations require measurements of $j\left(\mathrm{NO}_{3}\right)$ photolysis rates, which were not available during UWFPS. The median nocturnal nitrate production rate, however, changed by $<0.3 \%$ when this presunset time was varied between 0 and $2 \mathrm{~h}$. Photolysis rates during this time were also calculated from those measured during the WINTER campaign (Sect. S1.4.3; Shetter and Müller, 1999). While WINTER photolysis rates may have been larger than those during Utah PCAP events, the median modeled nocturnal nitrate production rate showed a small sensitivity $(<2.8 \%)$ to $\pm 40 \%$ changes in these values (Sect. S1.4.3). Additional uncertainties in air age (i.e., simulation start time and duration), however, may still serve to overpredict $\mathrm{N}_{2} \mathrm{O}_{5}$ loss rates and nocturnal nitrate based on previous sensitivity studies (McDuffie et al., 2018b). A combination of these assumptions will lead to a greater uncertainty in model results near sunset, as discussed in Sect. 3.3.2.

Fourth, air parcel mixing and deposition of gas-phase nitric acid were not included in base case simulations. Additional simulations, described in Sect. S1.4.2, included deposition using a first-order nitric acid loss constant of $2.6 \times 10^{-6} \mathrm{~s}^{-1}$, calculated from a boundary layer height of $800 \mathrm{~m}$; deposition velocity of $2.7 \mathrm{~cm} \mathrm{~s}^{-1}$ (Zhang et al., 2012); and gas/particle nitrate fraction of $8 \%$ from Franchin et al. (2018). The median nocturnal nitrate production rate increased by $<8 \%$ when this depositional loss of $\mathrm{HNO}_{3}$ was included. In contrast, modeled nitrate production was most sensitive $(-42.2 \%$ reduction) to the addition of a first-order loss process, meant to simulate air parcel dilution and $\mathrm{O}_{3}$ entrainment from vertical mixing between the RL and free troposphere (Table S4). Based on a previous analysis by Womack et al. (2019), the dilution rate constant was estimated to be $1.3 \times 10^{-5} \mathrm{~s}^{-1}$ in the RL, with a possible range of 1.2 to $2.5 \times 10^{-5} \mathrm{~s}^{-1}$ (described in Sect. S1.4.1). Results from simulations that include dilution are discussed further in the final section.

Finally, the absolute uncertainty associated with each individual nocturnal nitrate production rate was calculated from the quadrature addition of the uncertainties associated with sensitivity tests described above and the $\mathrm{NO}_{2}, \mathrm{O}_{3}, \mathrm{~N}_{2} \mathrm{O}_{5}$, and $\mathrm{ClNO}_{2}$ measurements used as model fit parameters $(<6 \%$ for all tests). Production rates derived from model fits to observations as well as the absolute uncertainties associated with all 17 sensitivity tests are shown as a time series in Fig. S3. Dilution contributes $92 \%$ of the total uncertainty (light blue in Fig. S3), on average. Both the base case results (black dots) and those from simulations including the effects of air parcel dilution are discussed in Sect. 3.3.3.

\section{Results and discussion}

\section{1 $\mathbf{P M}_{2.5}$ in Salt Lake Valley - winter 2017}

To provide an overview of wintertime pollution events in the SLV, Fig. 4 shows a time series of total $\mathrm{PM}_{2.5}$ mass ( 1 and $24 \mathrm{~h}$ averages) measured at the UDAQ Hawthorne (HW) site (Fig. 1) from 1 December 2016 to 22 February 2017. Additional time series of ground-based $\mathrm{PM}_{2.5}$ measurements for all three Utah NAAs are provided in Franchin et al. (2018). The SLV data in Fig. 4 show four pollution events that exceeded the NAAQS during the 2016-2017 winter. Calculated from $24 \mathrm{~h}$ measurements, the four largest pollution events during December 2016 and January 2017 had daily PM $_{2.5}$ buildup rates that ranged from 3.7 to $15.6 \mu \mathrm{g} \mathrm{m}^{-3} \mathrm{~d}^{-1}$ (see Fig. 4), encompassing the daily rates reported previously in the same valley (Whiteman et al., 2014; Silcox et al., 2012; Baasandorj et al., 2017). The last two major pollution events (10-22 January, event no. 3; and 25 January-5 February, event no. 4) overlapped with flights during UWFPS, shown by the gray shading in Fig. 4. Average non-refractory (NR) $\mathrm{PM}_{1}$ aerosol mass fractions measured during these periods by the TO AMS showed that the aerosol was primarily composed of $\mathrm{NH}_{4} \mathrm{NO}_{3}$ (Fig. 4 pie charts). The sum of $\mathrm{NO}_{3}^{-}$ and $\mathrm{NH}_{4}^{+}$contributed to $76.6 \%$ and $74.0 \%$ of the total $\mathrm{PM}_{1}$ mass measured during the last two pollution episodes (74\% average; Franchin et al., 2018), which agree with previous ground-based observations (e.g., Baasandorj et al., 2017) of past seasons. Nitrate alone contributed to an average $57 \%$ and $58 \%$ of the total aerosol mass during pollution episodes no. 3 and no. 4, respectively. During the relatively clean period sampled between 8 and 12 February 2017, the combined $\mathrm{NH}_{4}^{+}+\mathrm{NO}_{3}^{-}$fraction decreased to an average of $57 \%$, with a larger relative contribution from aerosol organics. The remaining analyses here will focus on aircraft flights during the two late January pollution events (no. 3 and no. 4) to evaluate the contribution of nocturnal RL heterogeneous nitrogen chemistry to observed surface-level nitrate during pollution events.

\subsection{Limiting and excess reagents for $\mathrm{NH}_{4} \mathrm{NO}_{3}$ aerosol}

As $\mathrm{NH}_{4} \mathrm{NO}_{3}$ was the principal component of $\mathrm{PM}_{2.5}$ during pollution events in the SLV (Fig. 4), the contribution from heterogeneous reactive nitrogen processes is dependent on whether $\mathrm{NH}_{4} \mathrm{NO}_{3}$ formation is limited by the availability of gas-phase $\mathrm{NH}_{3}$ or $\mathrm{HNO}_{3}$. Under ambient conditions, gasphase $\mathrm{NH}_{3}$ and $\mathrm{HNO}_{3}$ are assumed to be in a thermodynamic equilibrium with their particulate equivalents $\left(\mathrm{NO}_{3}^{-}(\mathrm{p})\right.$ and $\left.\mathrm{NH}_{4}^{+}(\mathrm{p})\right)$. The limiting reagent can therefore be inferred from the ratio of total oxidized $\left(\mathrm{HNO}_{3}(\mathrm{~g})+\mathrm{NO}_{3}^{-}(\mathrm{p})\right)$ to total reduced nitrogen $\left(\mathrm{NH}_{x}=\mathrm{NH}_{3}(\mathrm{~g})+\mathrm{NH}_{4}^{+}(\mathrm{p})\right)$, shown in Eq. (3). This ratio does not account for other aerosol components such as $\left(\mathrm{NH}_{4}\right)_{2} \mathrm{SO}_{4}, \mathrm{NH}_{4} \mathrm{HSO}_{4}$, and $\mathrm{NH}_{4} \mathrm{Cl}$ but should generally represent the $\mathrm{NH}_{4} \mathrm{NO}_{3}$ aerosol system when partic- 


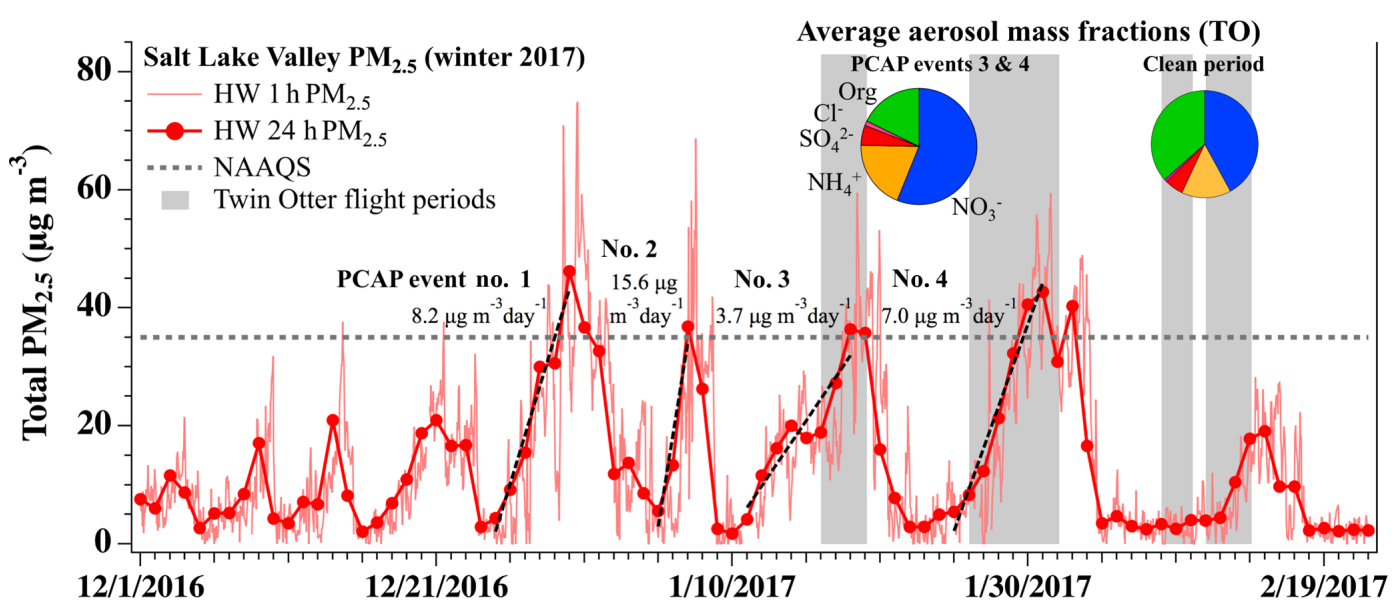

Figure 4. Time series of total $\mathrm{PM}_{2.5}$ mass $\left(\mu \mathrm{g} \mathrm{m}^{-3}\right)$ ( 1 and $24 \mathrm{~h}$ averages) for the 2016-2017 winter, measured at the Hawthorne (HW) UDAQ site in the SLV. Dashed black lines are daily $\mathrm{PM}_{2.5}$ accumulation rates (rates given in Figure). The $24 \mathrm{~h}$ EPA national ambient air quality standard (NAAQS) for $\mathrm{PM}_{2.5}\left(35 \mu \mathrm{g} \mathrm{m}{ }^{-3}\right)$ is shown by the dashed gray line. Gray shading indicates days when the TO aircraft was flying during UWFPS. Average aerosol mass fractions measured by the AMS aboard the TO are given in pie charts for polluted and clean conditions. Aerosol components are colored by nitrate (blue), ammonium (gold), sulfate (red), non-refractory chloride (pink), and organics (green).

ulate concentrations of sulfate and inorganic chloride are low, as was observed during UWFPS 2017 (Fig. 4 and Franchin et al., 2018). A nitrogen ratio greater than 1 indicates that oxidized nitrogen is in excess and $\mathrm{NH}_{4} \mathrm{NO}_{3}$ particle formation is limited by the presence of $\mathrm{NH}_{3}$. Conversely, a ratio smaller than 1 indicates that formation is limited by the presence of $\mathrm{HNO}_{3}$, which itself is limited by the oxidation rate of $\mathrm{NO}_{x}$. In a $\mathrm{HNO}_{3}$-limited system, $\mathrm{NH}_{4} \mathrm{NO}_{3}$ formation will be sensitive to changes in $\mathrm{HNO}_{3}$ concentrations resulting from both day- and nighttime $\mathrm{NO}_{x}$ oxidation processes. Daytime $\mathrm{NO}_{x}$ oxidation rates during winter will depend on specific conditions but are generally slower, such that nighttime oxidation may play a dominant role (e.g., Wood et al., 2005; Kenagy et al., 2018).

$\mathrm{N}$ Ratio $=\frac{\mathrm{HNO}_{3}(\mathrm{~g})+\mathrm{NO}_{3}^{-}(\mathrm{p})}{\mathrm{NH}_{3}(\mathrm{~g})+\mathrm{NH}_{4}^{+}(\mathrm{p})}$

A time series of nitrogen ratios in the SLV between 17 January and 1 February is shown in Fig. 5a, calculated from $10 \mathrm{~s}$ averaged (AMS frequency) measurements of gas- and particle-phase compounds aboard the TO aircraft. Figure 5a shows that $\mathrm{NH}_{4} \mathrm{NO}_{3}$ particle formation in the SLV during pollution episodes was largely limited by $\mathrm{HNO}_{3}$ (median ratio 0.77 ) but highly variable (range of $0.1-1.9$ ) and time dependent, with the frequency of $\mathrm{NH}_{3}$-limited conditions increasing throughout both late January pollution events. The color scale in Fig. 5a and the vertical profiles of average and 10th-90th percentile nitrogen ratios in Fig. 5b further show that the lowest nitrogen ratios corresponded to the lowest altitudes. This evidence of $\mathrm{HNO}_{3}$ limitation near the ground is consistent with all previous ground-based observations that show exclusive $\mathrm{HNO}_{3}$ limitation in the SLV (Kelly et al.,
2013; Utah Division of Air Quality, 2014c). The increased frequency of $\mathrm{NH}_{3}$-limited points throughout both pollution episodes (Fig. 5a), however, is opposite the trend predicted by Baasandorj et al. (2017), who suggested that observed surface-level oxidant depletion should lead to more $\mathrm{HNO}_{3}-$ limited conditions over time. Events of $\mathrm{NH}_{3}$ limitation (excess $\mathrm{HNO}_{3}$ ) during 2017, however, only occurred at the highest altitudes (panel $b$ ), and their increasing frequency with time (panel a) is consistent with these events reflecting negative $\mathrm{NH}_{3}$ gradients away from the surface and/or the production of $\mathrm{HNO}_{3}$ aloft from nocturnal $\mathrm{N}_{2} \mathrm{O}_{5}$ chemistry. The rate of $\mathrm{HNO}_{3}$ production from nocturnal heterogeneous chemistry is expected to be maximized at higher altitudes, removed from $\mathrm{NO}$ emissions and $\mathrm{O}_{3}$ titration at the surface (Fig. 2). Results here are also consistent with aerosol thermodynamic modeling studies by Franchin et al. (2018), who found that simulations of total $\mathrm{PM}_{1}$ mass during UWFPS flights over the SLV were proportionally sensitive to $50 \%$ reductions in total nitrate. Additional simulations by Franchin et al. (2018), however, also showed near 50\% $\mathrm{PM}_{1}$ reductions with $50 \%$ reductions in total ammonium $\left(\mathrm{NH}_{3}+\mathrm{NH}_{4}^{+}\right)$, indicating that $50 \%$ ammonium reductions may be enough to shift the SLV from the $\mathrm{HNO}_{3}$ to $\mathrm{NH}_{3}$-limited regime. This is consistent with nitrogen ratios in Fig. 5 approaching and exceeding values of 1 .

\subsection{Nitrate production via heterogeneous reactive nitrogen chemistry}

The absolute amount of nitrate that is chemically produced from heterogeneous chemistry will depend on the production rates of the nitrate radical and gas-phase $\mathrm{N}_{2} \mathrm{O}_{5}$ (Sect. 3.3.1), the $\mathrm{N}_{2} \mathrm{O}_{5}$ aerosol uptake efficiency (Sect. 3.3.2), and the 

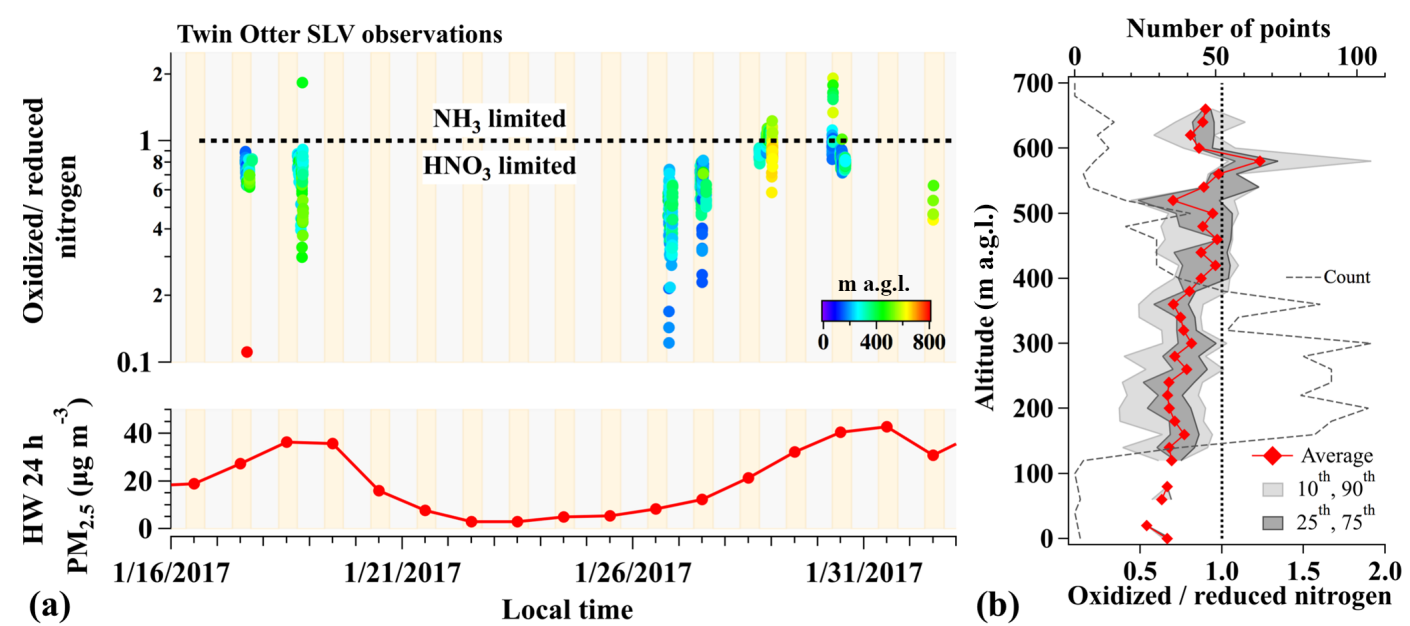

Figure 5. (a, top) Time series of the ratio of total oxidized $\left(\mathrm{HNO}_{3}+\mathrm{NO}_{3}^{-}\right)$to reduced $\left(\mathrm{NH}_{3}+\mathrm{NH}_{4}^{+}\right)$nitrogen between 16 January and 1 February 2017 (10 s averages), calculated from TO observations over the SLV. Individual nitrogen ratios are colored by aircraft altitude (m a.g.1.). Yellow and gray shading indicate times of day and night, respectively. (a, bottom) $\mathrm{PM}_{2.5}$ mass (24 h average) measured at the HW ground site. (b) Vertical profile of oxidized-to-reduced nitrogen ratios from panel (a). Diamonds represent the average values in each altitude bin and gray shading shows the 10th-90th (light gray) and 25th-75th (dark gray) percentiles. The number of points in each bin is shown by the gray dashed line. The vertical black line illustrates a nitrogen ratio of 1.

yields of $\mathrm{ClNO}_{2}$ and $\mathrm{HNO}_{3}$ (Sect. 3.3.2), which are quantified below. The final section (Sect. 3.3.3) presents forwardintegrated box model simulations to further quantify the nocturnal nitrate production rate and estimate the contribution of this chemistry to $\mathrm{NH}_{4} \mathrm{NO}_{3}$ formation during January 2017 in the SLV.

\subsubsection{Maximum instantaneous nitrate production rates}

An upper-limit estimate of the instantaneous aerosol nitrate production rate from heterogeneous $\mathrm{N}_{2} \mathrm{O}_{5}$ chemistry is defined here as $P_{\mathrm{NO}_{3}^{-} \text {,max }}$. This rate can be calculated as 2 times the gas-phase production rate of the $\mathrm{NO}_{3}$ radical $\left(P_{\mathrm{NO}_{3}}\right)$, given that the reaction between $\mathrm{NO}_{2}$ and $\mathrm{O}_{3}$ (Eqs. 4-6), rather than $\mathrm{N}_{2} \mathrm{O}_{5}$ uptake, is the rate-limiting step for nitrate formation (discussed below). In Eq. (4), $P_{\mathrm{NO}_{3}}$ is calculated in units of molecules per cubic centimeter per second (molec. $\mathrm{cm}^{-3} \mathrm{~s}^{-1}$ ) but is typically reported in units of $\mathrm{ppbv} \mathrm{h}^{-1}$ as shown here. The reaction kinetics in Eq. (5) between $\mathrm{NO}_{2}$ and $\mathrm{O}_{3}$ are from the 2008 IUPAC recommendation (IUPAC, 2008), ND is the number density of ambient air, and $P_{\mathrm{NO}_{3}^{-} \text {, max }}$ in Eq. (6) is calculated after $P_{\mathrm{NO}_{3}}$ has been converted to units of micrograms per cubic meter per hour $\left(\mu \mathrm{g} \mathrm{m}^{-3} \mathrm{~h}^{-1}\right)$, as detailed in Sect. S2. This calculation estimates a maximum contribution of $\mathrm{N}_{2} \mathrm{O}_{5}$ heterogeneous chemistry to nitrate production as it assumes (1) $\mathrm{N}_{2} \mathrm{O}_{5}$ is produced quantitatively from $\mathrm{NO}_{3}$ (i.e., no competing reaction of $\mathrm{NO}_{3}+\mathrm{VOC}$ ), (2) $\mathrm{N}_{2} \mathrm{O}_{5}$ is produced at the rate of $\mathrm{NO}_{3}$ production (valid under cold conditions that shift the $\mathrm{NO}_{3}-$ $\mathrm{N}_{2} \mathrm{O}_{5}$ equilibrium to favor of $\mathrm{N}_{2} \mathrm{O}_{5}$ ), (3) $\mathrm{N}_{2} \mathrm{O}_{5}$ is efficiently taken up onto aerosol, and (4) aqueous-phase reactions form two molecules of $\mathrm{HNO}_{3}$ for every molecule of $\mathrm{N}_{2} \mathrm{O}_{5}$ (i.e.,

$$
\begin{aligned}
& \left.\varphi\left(\mathrm{ClNO}_{2}\right)=0\right) . \\
& P_{\mathrm{NO}_{3}}\left[\mathrm{ppbvh}{ }^{-1}\right]=\frac{k_{4}\left[\mathrm{O}_{3}\right]\left[\mathrm{NO}_{2}\right]}{\mathrm{ND}\left[\mathrm{molec} . \mathrm{cm}^{-3}\right]} \cdot 3600\left[\mathrm{sh}^{-1}\right] \\
& \quad \cdot 1 \times 10^{9}[\mathrm{ppbv}] \\
& k_{4}\left[\mathrm{~cm}^{3} \text { molecule }{ }^{-1} \mathrm{~s}^{-1}\right]=1.4 \times 10^{-13} e^{(-2470 / T)} \\
& P_{\mathrm{NO}_{3}^{-}, \max }\left[\mu \mathrm{g} \mathrm{m}^{-3} \mathrm{~h}^{-1}\right]=2 \cdot\left(P_{\mathrm{NO}_{3}}\left[\mu \mathrm{g} \mathrm{m}^{-3} \mathrm{~h}^{-1}\right]\right)
\end{aligned}
$$

The value of $P_{\mathrm{NO}_{3}^{-} \text {,max }}$ is expected to vary with altitude due to boundary layer dynamics and surface $\mathrm{NO}_{x}$ emissions that can deplete $\mathrm{O}_{3}$ at night near the surface, as described previously in Baasandorj et al. (2017). The time series in Fig. 6a illustrates that the $\mathrm{O}_{3}$ measured at HW was frequently absent at night during the third and fourth pollution events in January 2017. As surface-level $\mathrm{O}_{3}$ was titrated overnight, ground-site data cannot provide direct information about $P_{\mathrm{NO}_{3}^{-} \text {,max }}$ aloft in the RL. In the absence of vertical observations during pollution events in 2016 , a previous analysis by Baasandorj et al. (2017) used late-afternoon measurements at the $\mathrm{HW}$ ground site to predict $\mathrm{NO}_{3}$ production rates $\left(P_{\mathrm{NO}_{3}}\right)$ in the RL that varied from 0 up to $\sim 2 \mathrm{ppbvh}^{-1}$ ( $0-5 \mu \mathrm{g} \mathrm{m}^{-3} \mathrm{~h}^{-1}$ ), but with values frequently $<1 \mathrm{ppbv}^{-1}$. These values correspond to instantaneous nitrate production rates $\left(P_{\mathrm{NO}_{3}^{-}, \text {max }}\right)$ of $\sim 0-10 \mu \mathrm{g} \mathrm{m}^{-3} \mathrm{~h}^{-1}$, with typical values closer to $5 \mu \mathrm{g} \mathrm{m}^{-3} \mathrm{~h}^{-1}$. Late-afternoon estimates from the same site during 2017 (dashed lines in Fig. 6, from Eq. 6) suggest smaller $P_{\mathrm{NO}_{3}^{-} \text {, max }}$ rates in 2017 than in 2016, with values between 1 and $5 \mu \mathrm{g} \mathrm{m}^{-3} \mathrm{~h}^{-1}$ during UWFPS pollution events (Fig. 6a).

The bottom panels of Fig. 6b show the binned, vertical profiles of median, 25th, and 75th percentile instantaneous 

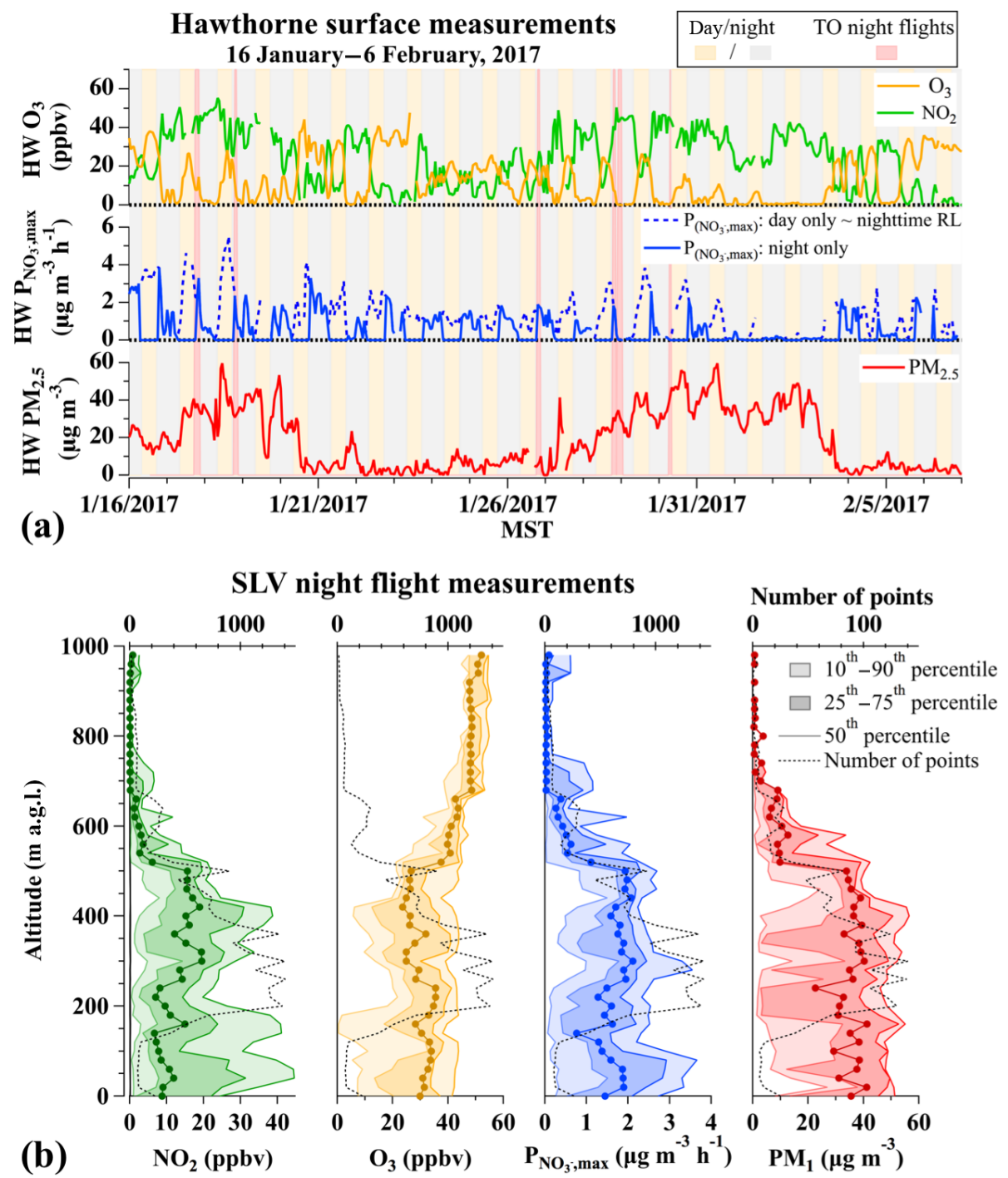

Figure 6. (a) Time series of $\mathrm{NO}_{2}, \mathrm{O}_{3}$ (top), $P_{\mathrm{NO}_{3}^{-} \text {, max }}$ (middle; see text for definition), and $\mathrm{PM}_{2.5}$ (bottom) measured at the $\mathrm{HW}$ ground site during 16 January-6 February 2017. $\mathrm{O}_{3}$ data during the middle January pollution event were corrected to account for a 4.5 ppbv offset in the HW measurements, as shown in Fig. S4. Aircraft flight times are shown by red shading. Dashed blue line shows the calculated $P_{\mathrm{NO}_{3}^{-}}$, max rates that would occur during the day if this mechanism were operative. Solid blue line assumes nitrate production from this mechanism during the day is zero. Late-afternoon $P_{\mathrm{NO}_{3}^{-}}$, max at the surface (dashed line) is roughly equivalent to the $P_{\mathrm{NO}_{3}^{-}}$, max expected in the RL at night. (b) Vertical profiles of $\mathrm{O}_{3}, \mathrm{NO}_{2}, P_{\mathrm{NO}_{3}^{-} \text {, max }}$ (1 s data), and $\mathrm{PM}_{1}$ (10 s data) measured from the aircraft on all night flights over the SLV. In each panel, light shaded regions show the 10th-90th percentile ranges, dark shaded regions are the 25 th-75th percentile ranges, and the solid lines are the 50th percentile. Dashed black lines show the number of points at each altitude.

$P_{\mathrm{NO}_{3}^{-}, \text {max }}$ values, along with aircraft observations of $\mathrm{O}_{3}$, $\mathrm{NO}_{2}$, and $\mathrm{PM}_{1}$ for all UWFPS night flights (red shaded regions in Fig. 6a). The vertical profiles show a relatively uniform distribution of $P_{\mathrm{NO}_{3}^{-} \text {, max }}$ with altitude through the lowest $600 \mathrm{~m}$. The dashed black lines also show that the number of points in each altitude bin was weighted toward the 100$500 \mathrm{~m}$ altitude range. The median instantaneous $P_{\mathrm{NO}_{3}^{-} \text {, max }}$ value in this polluted layer $(0-600 \mathrm{~m}$ a.g.l., meters above ground level) was $1.6 \mu \mathrm{g} \mathrm{m}^{-3} \mathrm{~h}^{-1}(N=21666)$. This value is at the low range of estimates of $1.6-5 \mu \mathrm{g} \mathrm{m}^{-3} \mathrm{~h}^{-1}$ that are predicted from late-afternoon ground-based observations on each flight day (dashed line in the middle panel of Fig. 6a), following the method of Baasandorj et al. (2017).

Vertical profiles in Fig. $6 \mathrm{~b}$ do not show evidence for a reduction in $P_{\mathrm{NO}_{3}^{-}, \max }$ or $\mathrm{O}_{3}$ near the surface, as is expected for $\mathrm{O}_{3}$ titration near the ground level (shown in panel a). The distribution in panel $b$, however, is affected by the location of the missed approaches/landings in the SLV (Salt Lake International and South Valley Regional airfields), which are further 


\section{SLV night measurements: January 28-29}

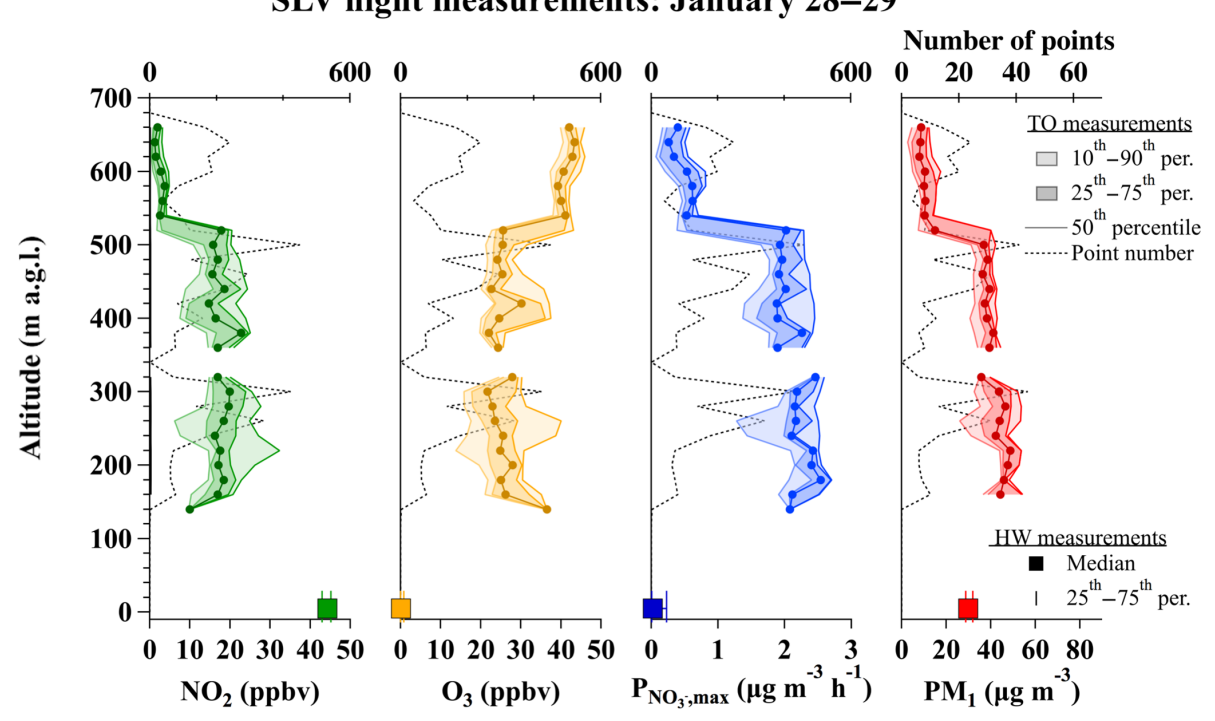

Figure 7. Vertical profiles of $\mathrm{NO}_{2}, \mathrm{O}_{3}, P_{\mathrm{NO}_{3}^{-}}$,max $\left(1 \mathrm{~s}\right.$ data), and $\mathrm{PM}_{1}$ (10 s data) measured from the TO aircraft during five box patterns, flown over the SLV urban core between 21:20 and 00:30 MST on 28 and 29 January. Percentiles and number of points at each altitude are shown as in Fig. 6. Square markers and error bars represent the median and 25th-75th percentile range of $\mathrm{NO}_{2}, \mathrm{O}_{3}, P_{\mathrm{NO}_{3}^{-}}$, and $\mathrm{PM}_{2.5}$ measured concurrently at the HW ground site.

from the urban center of Salt Lake City than the HW ground site (see Fig. 1). Vertical profiles to the surface over urban Salt Lake City were not possible due to a lack of airfields for missed approaches. Instead, the SLV flights often executed box patterns over the eastern Salt Lake basin at several altitudes. Figure 7 shows the vertical distribution of $P_{\mathrm{NO}_{3}^{-}, \max }$ values from these boxes on 28-29 January between 21:20 and 00:30 local time, compared to $P_{\mathrm{NO}_{3}^{-} \text {,max }}$ measured at the surface during the same interval. At 300 and $500 \mathrm{~m}$ a.g.l., the median (and interquartile range) $P_{\mathrm{NO}_{3}^{-} \text {,max }}$ was 2.2 (2.1 to 2.4) and 1.9 (1.8 to 2.1$) \mu \mathrm{g} \mathrm{m}^{-3} \mathrm{~h}^{-1}$, while at $650 \mathrm{~m}$, slightly above the most concentrated pollution layer, it was $0.5(0.3$ to 0.7$) \mu \mathrm{g} \mathrm{m}^{-3} \mathrm{~h}^{-1}$. The median value at the HW ground site, directly below the aircraft, was 0.02 (0.01 to 0.2$) \mu \mathrm{g} \mathrm{m}^{-3}$. These plots demonstrate that $P_{\mathrm{NO}_{3}^{-} \text {, max }}$ is typically low or zero at night near the surface within the urban area of Salt Lake City but large within the RL. Away from the urban area, the vertical distributions of $P_{\mathrm{NO}_{3}^{-}, \text {max }}$ are also likely more uniform (Fig. 6b) due to the lack of $\mathrm{O}_{3}$ titration within the nocturnal boundary layer. In the final section below, nightly integration of these instantaneous $P_{\mathrm{NO}_{3}^{-} \text {, max }}$ values are compared to box model predictions of total nitrate.

\subsubsection{Modeled uptake coefficients and production yields}

Both the aerosol uptake efficiency of $\mathrm{N}_{2} \mathrm{O}_{5}\left(\gamma\left(\mathrm{N}_{2} \mathrm{O}_{5}\right)\right)$ and the production yield of $\mathrm{ClNO}_{2}\left(\varphi\left(\mathrm{ClNO}_{2}\right)\right)$ are highly variable, dependent on aerosol composition, and can impact the absolute amount of nitrate formed from nocturnal heteroge- neous nitrogen chemistry. The nighttime formation of nitrate, however, is only limited by these processes when $\mathrm{N}_{2} \mathrm{O}_{5}$ uptake is inefficient and is instead limited by the oxidation rate of $\mathrm{NO}_{2}$ (Reaction $\mathrm{R} 4$ ) (discussed above) at sufficiently large values of $\gamma\left(\mathrm{N}_{2} \mathrm{O}_{5}\right)$.

As described in Sect. 2.2, an iterative box model was fit to observations of $\mathrm{NO}_{2}, \mathrm{O}_{3}, \mathrm{~N}_{2} \mathrm{O}_{5}$, and $\mathrm{ClNO}_{2}$ to quantify $\gamma\left(\mathrm{N}_{2} \mathrm{O}_{5}\right)$ and $\varphi\left(\mathrm{ClNO}_{2}\right)$ during pollution events. For the SLV alone $(N=1031)$, the distribution in Fig. 8 shows that $\gamma\left(\mathrm{N}_{2} \mathrm{O}_{5}\right)$ values ranged 4 orders of magnitude from $1 \times 10^{-3}$ to $>1$ with two modes centered near 0.01 and 0.08 . Values approaching or exceeding 1 are unphysical and suggest artifacts in the $\gamma\left(\mathrm{N}_{2} \mathrm{O}_{5}\right)$ determinations for UWFPS (see below), at least for the largest values. Values of $\varphi\left(\mathrm{ClNO}_{2}\right)$ encompassed the entire possible range of 0 to 1 (Fig. 8). The medians for this subset were 0.076 and 0.220 for $\gamma\left(\mathrm{N}_{2} \mathrm{O}_{5}\right)$ and $\varphi\left(\mathrm{ClNO}_{2}\right)$, respectively. For all UWFPS flights between 16 January and 1 February 2017, the median $\gamma\left(\mathrm{N}_{2} \mathrm{O}_{5}\right)$ and $\varphi\left(\mathrm{ClNO}_{2}\right)$ values in the RL $(N=2195)$ were 0.049 and 0.256 , respectively, derived from box model fits to observations. These values are compared to multiple derivation methods further below.

Compared to previous studies, the median $\gamma\left(\mathrm{N}_{2} \mathrm{O}_{5}\right)$ over the SLV was twice as large as the mode derived with a similar model using data from the Nitrogen, Aerosol Composition, and Halogens on a Tall Tower (NACHTT) campaign near Denver, Colorado, in winter 2011 (Wagner et al., 2013). Similarly, the median was over 5 times larger than the median calculated using the same model from the 2015 WINTER campaign (McDuffie et al., 2018b). The largest values during 
UWFPS exceeded those from both WINTER and NACHTT studies, while the smallest values were also larger than either of the respective minimums. The two most common suppression mechanisms that lead to reductions in $\gamma\left(\mathrm{N}_{2} \mathrm{O}_{5}\right)$ are associated with the presence of organic material and nitrate in the aerosol phase. Insoluble aerosol organics have been shown to suppress $\mathrm{N}_{2} \mathrm{O}_{5}$ uptake in previous laboratory studies (e.g., Griffiths et al., 2009; Thornton et al., 2003; McNeill et al., 2006; Thornton and Abbatt, 2005; Cosman et al., 2008; Badger et al., 2006; Folkers et al., 2003), and large organic mass fractions have been associated with $\gamma\left(\mathrm{N}_{2} \mathrm{O}_{5}\right)$ reductions in past field studies (Bertram et al., 2009; McDuffie et al., 2018b). The average dry mass fraction of aerosol organics (i.e., organic mass/total dry aerosol mass) during the SLV pollution events was less than half of the average during the WINTER campaign $(\sim 18 \%$ vs. $40 \%)$ and $40 \%$ lower than the average during NACHTT (27\%, Wagner et al., 2013). Aerosol nitrate can also suppress uptake as soluble nitrate facilitates the reformation of gas-phase $\mathrm{N}_{2} \mathrm{O}_{5}$ (Bertram and Thornton, 2009; Griffiths et al., 2009), and nitrate mass fractions have been negatively correlated with $\gamma\left(\mathrm{N}_{2} \mathrm{O}_{5}\right)$ in previous field studies (Wagner et al., 2013; Morgan et al., 2015; Riedel et al., 2012; Bertram et al., 2009; McDuffie et al., 2018b). The presence of sufficient aerosol water, however, can offset this nitrate suppression by promoting $\mathrm{N}_{2} \mathrm{O}_{5}$ aqueous solvation and reaction (e.g., Bertram and Thornton, 2009; Griffiths et al., 2009; Mentel et al., 1999; Wahner et al., 1998), resulting in increases in $\gamma\left(\mathrm{N}_{2} \mathrm{O}_{5}\right)$ with the ratio of water to nitrate (McDuffie et al., 2018b). The average dry mass fraction of aerosol nitrate was much larger during UWFPS $(60 \%)$ than during NACHTT (30\%, Wagner et al., 2013) or WINTER (15\%, McDuffie et al., 2018b). High-humidity conditions during UWFPS (77\% average RH during pollution events) resulted in average aerosol water mass fractions (i.e., water mass/aerosol dry mass + water mass) near $70 \%$, as calculated with an aerosol thermodynamic model, described in Franchin et al. (2018). This higher RH likely contributed to efficient $\mathrm{N}_{2} \mathrm{O}_{5}$ uptake during UWFPS despite the presence of aerosol nitrate. In fact, the largest $25 \%$ of UWFPS $\gamma\left(\mathrm{N}_{2} \mathrm{O}_{5}\right)$ values exceed the largest value (0.175) that has been reported from recent field studies (Fig. 4 in McDuffie et al., 2018b).

The median $\varphi\left(\mathrm{ClNO}_{2}\right)$ value of 0.220 during the SLV pollution events was 4 times larger than during the NACHTT campaign (Riedel et al., 2013; Wagner et al., 2013) but within a factor of 2 larger than the median derived during WINTER over the US east coast (McDuffie et al., 2018a). The SLV median was also similar to medians reported from previous ground-based studies across North America (Mielke et al., 2016, 2011, 2013; Wagner et al., 2012; Thornton et al., 2010). Heterogeneous $\mathrm{ClNO}_{2}$ production requires aerosol chloride (Reaction R6) (e.g., Behnke et al., 1997), and though a consistent geographic pattern in $\varphi\left(\mathrm{ClNO}_{2}\right)$ has not emerged from past studies (Fig. 2 in McDuffie et al., 2018a), heterogeneous chemistry in the vicinity of the Great
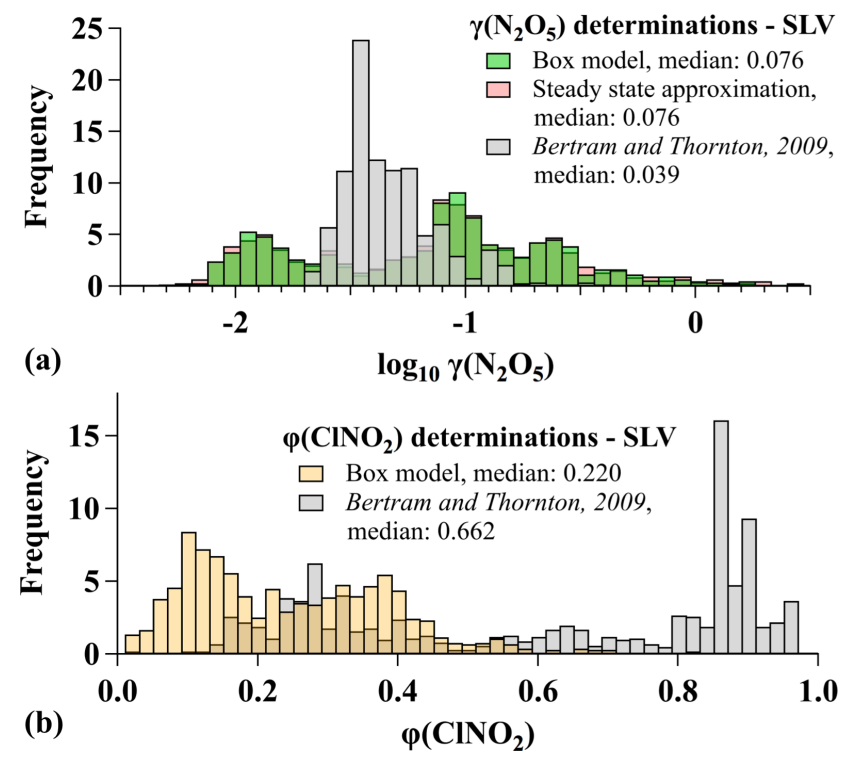

Figure 8. (a) Histograms of $\gamma\left(\mathrm{N}_{2} \mathrm{O}_{5}\right)$ determinations from the SLV during pollution events, calculated with the box model (green), steady-state approximation (pink), and parameterization from Bertram and Thornton (2009). (b) Histograms of $\varphi\left(\mathrm{ClNO}_{2}\right)$ determinations from the SLV during pollution events calculated with the box model (gold) and parameterization from Bertram and Thornton (2009) (gray).

Salt Lake appears to produce $\mathrm{ClNO}_{2}$ with the same efficiency as comparable measurements near North American ocean coastlines. $\mathrm{ClNO}_{2}$ production yields, however, remain smaller than those predicted based on measured aerosol composition, as discussed below.

While large $\gamma\left(\mathrm{N}_{2} \mathrm{O}_{5}\right)$ and moderate $\varphi\left(\mathrm{ClNO}_{2}\right)$ values indicate efficient nitrate production from heterogeneous chemistry during UWFPS, these values may be upper and lower limits, respectively. As discussed in Sect. 2.1, limited observations of VOC and photolysis rates, as well as uncertainties in air age, and dilution may cause the $k_{\mathrm{N}_{2} \mathrm{O}_{5}}$ and $k_{\mathrm{ClNO}_{2}}$ values (and subsequent $\gamma\left(\mathrm{N}_{2} \mathrm{O}_{5}\right)$ and $\left.\varphi\left(\mathrm{ClNO}_{2}\right)\right)$ to be over- and underpredicted, respectively. This is more likely near sunset where the model has an increased sensitivity to assumptions in simulation start time (McDuffie et al., 2018b). Uncertainties in gas-phase measurements may also contribute to uncertainties in the model predictions, though the level of uncertainty associated with these parameters is small (Table S4). Additional uncertainties in $k_{\mathrm{N}_{2} \mathrm{O}_{5}}$ and $k_{\mathrm{ClNO}_{2}}$ may arise from model assumptions of constant temperature and RH (i.e., rate constants and surface area) overnight. While model sensitivities to these uncertainties cannot be directly quantified, the percent growth in SA from nitrate accumulation is estimated to be less than the uncertainty in the dry SA measurement $(34 \%)$. As modeled $k_{\mathrm{N}_{2} \mathrm{O}_{5}}$ values are also consistent with those derived from observations (discussed below), this source of uncertainty is not discussed further. Overall, while 
the box model has a large number of uncertainties and assumptions, predictions of nocturnal nitrate production, which are subject to uncertainties in both $k_{\mathrm{N}_{2} \mathrm{O}_{5}}$ and $k_{\mathrm{ClNO}_{2}}$, are not highly sensitive to sources other than dilution (Table S4).

Independent of the model fits of $k_{\mathrm{N}_{2} \mathrm{O}_{5}}$ and $k_{\mathrm{ClNO}_{2}}$, unphysically large $\gamma\left(\mathrm{N}_{2} \mathrm{O}_{5}\right)$ values ( $>0.1$ in Fig. 8) may alternatively be an artifact arising from an under-measurement of ambient aerosol SA. Low aerosol SA would bias high the $\gamma\left(\mathrm{N}_{2} \mathrm{O}_{5}\right)$ calculation in Eq. (1) without influencing the model derivations of $k_{\mathrm{N}_{2} \mathrm{O}_{5}}$ and $k_{\mathrm{ClNO}_{2}}$. In this study, wet aerosol SA was calculated as described above by applying an $\mathrm{RH}$-dependent growth factor curve to the measured dry $\mathrm{PM}_{1}$ SA. Despite large concentrations of total dry SA (Fig. S2), an underprediction in the wet SA could arise from uncertainties in the hygroscopic growth curve or additional unmeasured SA from large particles $(>1 \mu \mathrm{m})$. Both factors would be exacerbated by the high-humidity conditions encountered during UWFPS since large, hydrated particles would not be sampled efficiently by the aerosol inlet and hygroscopic growth curves are highly uncertain above $\sim 95 \%$ RH (corresponding to $6.7 \%$ of the SLV data). A third possible cause of under-measured SA is the presence of fog under highhumidity conditions. Fog is well known to promote rapid heterogeneous processes (Lelieveld and Crutzen, 1990) and is associated with surface areas that can be orders of magnitude larger than accumulation mode aerosol. For example, fog has been demonstrated to lead to rapid $\mathrm{N}_{2} \mathrm{O}_{5}$ loss at a ground site in Hong Kong, during November-December 2013 (Brown et al., 2016). It is therefore possible that unmeasured SA under high-humidity conditions could bias the calculated $\gamma\left(\mathrm{N}_{2} \mathrm{O}_{5}\right)$ values high relative to values reported in previous literature. Any bias caused by aerosol SA, however, would not impact the model-derived $k_{\mathrm{N}_{2} \mathrm{O}_{5}}$ and $k_{\mathrm{ClNO}_{2}}$ values that are used to calculate nocturnal nitrate production rates in the final analysis below.

To further evaluate the UWFPS $\gamma\left(\mathrm{N}_{2} \mathrm{O}_{5}\right)$ and $\varphi\left(\mathrm{ClNO}_{2}\right)$ values, box model determinations are compared to two other derivation methods in Figs. 8 and S5. The first method calculates $\gamma\left(\mathrm{N}_{2} \mathrm{O}_{5}\right)$ from observations of temperature, SA, $\mathrm{NO}_{2}, \mathrm{O}_{3}$, and $\mathrm{N}_{2} \mathrm{O}_{5}$, based on the steady-state approximation $\left(\gamma\left(\mathrm{N}_{2} \mathrm{O}_{5}\right)_{\mathrm{ss}}\right)$, described by Brown et al. (2003) and defined in Sect. S4.1. This method shows excellent agreement with box model results (Figs. 8 and S5). The steady-state method has been shown in previous analyses to overpredict $\gamma\left(\mathrm{N}_{2} \mathrm{O}_{5}\right)$ values under cold, high- $\mathrm{NO}_{x}$ conditions, but only if the first-order rate constants for $\mathrm{NO}_{3}$ and $\mathrm{N}_{2} \mathrm{O}_{5}$ loss $\left(k_{\mathrm{NO}_{3}}\right.$ and $\left.k_{\mathrm{N}_{2} \mathrm{O}_{5}}\right)$ are modest (Brown et al., 2003). Both the steady-state and box model $\gamma\left(\mathrm{N}_{2} \mathrm{O}_{5}\right)$ values are consistent with a rapid first-order loss constant of $\mathrm{N}_{2} \mathrm{O}_{5}$ (median $k_{\mathrm{N}_{2} \mathrm{O}_{5}}=1.1 \times 10^{-3} \mathrm{~s}^{-1}$ ), suggesting the steady-state approach is valid for SLV conditions. The corresponding median lifetime $\left(1 / k_{\mathrm{N}_{2} \mathrm{O}_{5}}\right)$ of $14 \mathrm{~min}$ is, for example, much shorter than the lifetimes of $2-18 \mathrm{~h}$ calculated from a previous steady-state analysis of aircraft measurements over Texas in fall 2006 (Brown et al., 2009). Nevertheless, the color scale in Fig. S5 shows that the largest $\gamma\left(\mathrm{N}_{2} \mathrm{O}_{5}\right)$ values $(\geq 0.1)$ were exclusively derived for air sampled within $3 \mathrm{~h}$ of sunset ( $4.3 \mathrm{~h}$ simulation time), where previous analysis has shown the steady-state approximation to be least reliable. As Fig. S5 shows large values of $\gamma\left(\mathrm{N}_{2} \mathrm{O}_{5}\right)$ from both the box model and the steady-state analysis during this time, there may be a common bias between the methods if these values are indeed too large.

The second method calculates both $\gamma\left(\mathrm{N}_{2} \mathrm{O}_{5}\right)$ and $\varphi\left(\mathrm{ClNO}_{2}\right)$ using laboratory-derived parameterizations from Bertram and Thornton (2009) (BT09), based on the aerosol volume-to-surface-area ratio; $\mathrm{N}_{2} \mathrm{O}_{5}$ solubility (Fried et al., 1994); aerosol molarities of water, nitrate, and chloride; and laboratory-derived reaction rate constant ratios. Further details of each parameterization are provided in Sect. S4.2. These parameterizations have had mixed success in reproducing previous field-derived values (e.g., Bertram et al., 2009; Riedel et al., 2012; McDuffie et al., 2018a, b) but are commonly used to predict $\mathrm{N}_{2} \mathrm{O}_{5}$ uptake and $\mathrm{ClNO}_{2}$ production on internally mixed inorganic aerosol when $\mathrm{N}_{2} \mathrm{O}_{5}$ chemistry is included in global models (e.g., Sarwar et al., 2014; Shah et al., 2018).

Results in Fig. S5 show that the median $\gamma\left(\mathrm{N}_{2} \mathrm{O}_{5}\right)$ value predicted by the BT09 parameterization is within a factor of 2 of the box model median but that this parameterization does not reproduce the observed variability (Fig. 8). For $\varphi\left(\mathrm{ClNO}_{2}\right)$, the BT09 parameterization largely overpredicts model-derived values with a median of 0.66 relative to the model median of 0.22 (Fig. S5). This overprediction is consistent with all previous studies to compare parameterized and field-derived $\varphi\left(\mathrm{ClNO}_{2}\right)$ results (Wagner et al., 2013; Wang et al., 2017a, b; Ryder et al., 2015; Thornton et al., 2010; Riedel et al., 2013; Tham et al., 2018; McDuffie et al., 2018a). These results also suggest that the parameterization would need to be reduced by $68 \%$ for agreement with the box model median, similar to the $74 \%-85 \%$ reduction required for agreement of this parameterization with the WINTER campaign median (McDuffie et al., 2018a). The possible presence of additional, refractory-phase chloride (i.e., $\mathrm{NaCl}, \mathrm{CaCl}_{2}$, and $\mathrm{KCl}$ ) in the accumulation mode would increase the predicted $\gamma\left(\mathrm{N}_{2} \mathrm{O}_{5}\right)$ and improve agreement with the box model but would further degrade the agreement of $\varphi\left(\mathrm{ClNO}_{2}\right)$.

Lastly, the empirical $\gamma\left(\mathrm{N}_{2} \mathrm{O}_{5}\right)$ parameterization from McDuffie et al. (2018b) was applied to UWFPS data, though only an estimated range for the campaign median is presented due to uncertainties in the aerosol $\mathrm{O}: \mathrm{C}$ ratio and aerosol organic density, both required for this calculation (discussed in Sect. S4.2). This parameterization models $\mathrm{N}_{2} \mathrm{O}_{5}$ uptake onto an aqueous inorganic particle with a resistive organic coating, with the coating thickness determined by the volume ratio of inorganic to total aerosol components (McDuffie et al., 2018b; Riemer et al., 2009; Anttila et al., 2006). By estimating a range of $\mathrm{O}: \mathrm{C}$ ratios using the improved-ambient $\mathrm{O}: \mathrm{C}$ ratio method from 
Canagaratna et al. (2015) and AMS organic $m / z 44$ fraction (Fig. 6, Franchin et al., 2018), assuming an organic density of $1.3 \mathrm{~g} \mathrm{~cm}^{-3}$ (e.g., Kuwata et al., 2012) to estimate the organic-associated volume, and applying additional constants described in Sect. S4.2, this parameterization estimated a median $\gamma\left(\mathrm{N}_{2} \mathrm{O}_{5}\right)$ between $60 \%$ and $85 \%$ lower than the box model. Though there are large uncertainties in the required parameters, these results suggest that during pollution events (1) aerosol organics are not surface active, (2) aerosol organics are not resistive toward $\mathrm{N}_{2} \mathrm{O}_{5}$, or (3) box model $\gamma\left(\mathrm{N}_{2} \mathrm{O}_{5}\right)$ values are overpredicted due to missing SA (e.g., fog, Sect. 3.3.2) or other simplifying assumptions (e.g., dilution) discussed above.

Despite disagreement between the box model and parameterizations, the $\gamma\left(\mathrm{N}_{2} \mathrm{O}_{5}\right)$ values predicted by all three methods are large enough, in combination with the large measured aerosol SA, to fall within the range where models of nighttime chemistry are insensitive to variation in uptake efficiency (e.g., Macintyre and Evans, 2010; Riemer et al., 2003; Wang et al., 2018). Under these conditions, the $\mathrm{NO}_{2}$ gas-phase oxidation rate (i.e., $P_{\mathrm{NO}_{3}^{-}}$), rather than $\mathrm{N}_{2} \mathrm{O}_{5}$ uptake, becomes the limiting factor to $\mathrm{HNO}_{3}$ formation. As further evidence of this limitation, the median lifetime of $\mathrm{NO}_{2}$ with respect to $\mathrm{O}_{3}\left(\tau_{\mathrm{NO}_{2}}=1 /\left(k_{1}\left[\mathrm{O}_{3}\right]\right)\right)$ was $9 \mathrm{~h}$ while the lifetime of $\mathrm{N}_{2} \mathrm{O}_{5}\left(\tau_{\mathrm{N}_{2} \mathrm{O}_{5}}=1 / k_{\mathrm{N}_{2} \mathrm{O}_{5}}\right)$ was just 14 min, resulting in low $\mathrm{N}_{2} \mathrm{O}_{5}$ mixing ratios (median $=0.03 \mathrm{ppbv}$ ) during the SLV pollution events (Fig. S6). In addition, explicit box modeling of day- and nighttime chemical processes during UWFPS by Womack et al. (2019) also showed that the production of $\mathrm{O}_{x}$, total $\left(=\mathrm{NO}_{2}+\mathrm{O}_{3}+2 \cdot \mathrm{NO}_{3}+1.5 \cdot\left(\mathrm{HNO}_{3}+\right.\right.$ particulate nitrate) $+\mathrm{ClNO}_{2}+3 \cdot \mathrm{N}_{2} \mathrm{O}_{5}+$ others) was insensitive $(<1.5 \%)$ to order-of-magnitude changes in $\gamma\left(\mathrm{N}_{2} \mathrm{O}_{5}\right)$. Short lifetimes of $\mathrm{N}_{2} \mathrm{O}_{5}$ relative to $\mathrm{NO}_{2}$ and nitrate insensitivity to $\gamma\left(\mathrm{N}_{2} \mathrm{O}_{5}\right)$ both indicate that nocturnal heterogeneous chemistry contributes to $\mathrm{NH}_{4} \mathrm{NO}_{3}$ formation but that absolute production is limited by gas-phase kinetics rather than aerosol composition and $\gamma\left(\mathrm{N}_{2} \mathrm{O}_{5}\right)$. This insensitivity to $\gamma\left(\mathrm{N}_{2} \mathrm{O}_{5}\right)$ provides confidence in the ability of the box model to predict the magnitude of nocturnal nitrate production in the SLV, regardless of uncertainties in $\gamma\left(\mathrm{N}_{2} \mathrm{O}_{5}\right)$.

\subsubsection{Modeled nocturnal nitrate production rates and contribution of heterogeneous chemistry to total $\mathrm{NH}_{4} \mathrm{NO}_{3}$ aerosol accumulation rates}

As described in Sect. 2.2 and shown in Fig. 3, the box model simulates the amount of total nitrate $\left(\mathrm{HNO}_{3}+\mathrm{NO}_{3}^{-}\right)$produced from heterogeneous chemistry over the course of a single night. This amount of nitrate, in units of $\mu \mathrm{g} \mathrm{m}^{-3}$ per night, is in addition to any nitrate present at sunset from the previous day (e.g., Fig. 3). Figure 9 shows the distribution of nightly nitrate production predicted by base case simulations ( $N=1031)$, ranging from $\sim 0$ to $31 \mu \mathrm{g} \mathrm{m}^{-3}$ nitrate per night, with a median of $9.9 \mu \mathrm{g} \mathrm{m}^{-3}$ nitrate per night.

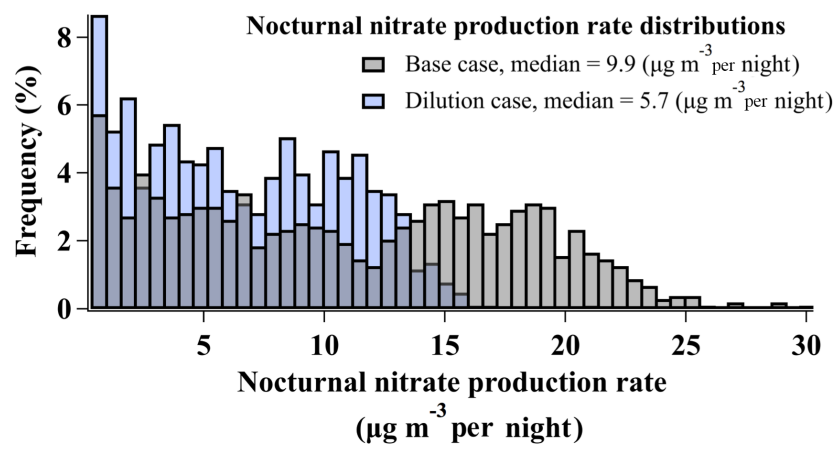

Figure 9. Histograms of nocturnal nitrate production rates $\left(\mu \mathrm{g} \mathrm{m}^{-3}\right.$ per night) predicted by base case simulations and simulations incorporating a first-order dilution loss process with rate constant $k_{\text {dilution }}=1.3 \times 10^{-5} \mathrm{~s}^{-1}$.

In addition to evidence from the previous section, comparisons between the base case results and integrated $P_{\mathrm{NO}_{3}^{-} \text {, max }}$ values from Sect. 3.3.1 also suggest that nocturnal nitrate production is limited by the rate of $\mathrm{NO}_{2}$ oxidation rather than the efficiency of $\mathrm{N}_{2} \mathrm{O}_{5}$ aerosol uptake. Based on the calculations in Sect. 3.1, upper-limit $P_{\mathrm{NO}_{3}^{-} \text {, max }}$ values, integrated over an average $14 \mathrm{~h}$ night and reduced to account for a $\varphi\left(\mathrm{ClNO}_{2}\right)$ value of 0.2 , ranged from $<0.5$ to $>$ $40 \mu \mathrm{g} \mathrm{m}^{-3}$ per night, with a median of $20.2 \mu \mathrm{g} \mathrm{m}^{-3}$ per night $(N=21666)$. To more directly compare with box model results, the subset of points with simultaneous $\gamma\left(\mathrm{N}_{2} \mathrm{O}_{5}\right)$ determinations had a median of $10.6 \mu \mathrm{g} \mathrm{m}^{-3}$ per night, which is slightly larger but agrees well with the box-model-predicted median of $9.9 \mu \mathrm{g} \mathrm{m}^{-3}$ per night. As described in Sect. 3.3.1, the $P_{\mathrm{NO}_{3}^{-}}$,max calculation assumes efficient $\mathrm{N}_{2} \mathrm{O}_{5}$ uptake and only considers nitrate production to be limited by gasphase kinetics. Observed agreement between the integrated $P_{\mathrm{NO}_{3}^{-} \text {,max }}$ values and box-model-predicted production rates therefore suggests that nitrate production may be largely limited by gas-phase oxidation rather than multiphase processes. As a result, the large variability in predicted nitrate production rates is reflective of the variability in the observed $\mathrm{NO}_{3}$ radical production rates (Fig. 6).

Uncertainties associated with base case production rates are discussed in Sect. 2.2.2 and shown as a time series in Fig. S3. Air parcel dilution associated with the vertical entrainment of air from the free troposphere (Sect. S1.4.1) was the largest source of uncertainty (Table S4, Fig. S3). This process was not included in base case simulations, though mixing/dilution has been observed and predicted in analyses of WINTER nighttime flights (Kenagy et al., 2018; McDuffie et al., 2018b). Estimating the impact of dilution by including a single first-order dilution rate constant $\left(k_{\text {dilution }}\right)$ of $1.3 \times 10^{-5} \mathrm{~s}^{-1}$ reduced the median nocturnal nitrate production rate by $42 \%$ to $5.7 \mu \mathrm{g} \mathrm{m}^{-3}$ per night and resulted in a smaller range of production rates $\left(\sim 0\right.$ to $16 \mu \mathrm{g} \mathrm{m}^{-3}$ per night) relative to base case simulations in Fig. 9. As de- 
scribed in Womack et al. (2019) (and in Sect. S1.4.1), a single first-order dilution rate constant of $8 \times 10^{-6} \mathrm{~s}^{-1}$ was derived for pollution event no. 4 in the SLV by fitting a box model to best reproduce the day-to-day buildup of observed $\mathrm{O}_{x}$,total between 28 January and 1 February at the UU ground site. In the model described by Womack et al. (2019), this rate constant was then scaled up by $40 \%$ when simulating the nocturnal RL in order to maintain constant dilution and account for the reduced volume relative to the mixed daytime boundary layer. While dilution/entrainment rates may vary from day to night, the method of Womack et al. (2019) represents the single number that would best represent the average rate. The same procedure is followed here with a resulting $k_{\text {dilution }}$ value of $1.3 \times 10^{-5} \mathrm{~s}^{-1}$, which is $\sim 60 \%$ lower than $k_{\text {dilution }}$ from the WINTER campaign, derived from observations of $\mathrm{NO}_{y}\left(=\mathrm{NO}+\mathrm{NO}_{2}+\mathrm{NO}_{3}+2 \cdot \mathrm{N}_{2} \mathrm{O}_{5}+\mathrm{ClNO}_{2}+\mathrm{RONO}_{2} \ldots\right)$ overnight in a single RL air parcel over the eastern US coast (McDuffie et al., 2018b). As processes relevant to RL dilution were not directly measured during UWFPS, there are uncertainties associated with this $k_{\text {dilution }}$ estimation. For instance, based on the modeled surface albedo in Womack et al. (2019), $k_{\text {dilution }}$ could have reproduced observed $\mathrm{O}_{x \text {,total }}$ mixing ratios with scaled values ranging between $1.2 \times 10^{-5}$ and $2.5 \times 10^{-5} \mathrm{~s}^{-1}$ (Fig. S10, Womack et al., 2019). This particular range of loss rate constants predicts median nitrate production rates in the SLV between 3.6 and $6.1 \mu \mathrm{g} \mathrm{m}^{-3}$ per night.

Modeled nitrate production rates are further compared in Fig. 10 to the average daily accumulation of surface-level nitrate aerosol during pollution event no. 4 at the HW ground site. This ground-based accumulation rate (red diamond in Fig. 10a) was taken as the slope of the $24 \mathrm{~h}$ average $\mathrm{PM}_{2.5}$ observations at $\mathrm{HW}$ (scaled by 0.58 ; average $\mathrm{NO}_{3}^{-}$fraction from Fig. 4) during the first $6 \mathrm{~d}$ of event no. 4, before it began to degrade on 1 February 2017 (Fig. 10b). Only data from event no. 4 are assessed here as this was the only PCAP sampled with the aircraft on multiple nights. Figure 10a shows this average, $24 \mathrm{~h}$ surface accumulation rate of $4.6 \mu \mathrm{g} \mathrm{m}^{-3} \mathrm{~d}^{-1}$ (red diamond) compared to the 10th-90th percentile distributions, medians, and averages of the nocturnal production rates predicted by base case box model simulations (gray) and simulations including the effects of $24 \mathrm{~h}$ dilution (blue), described below.

Comparing modeled RL chemical nitrate production to the observed ground-based accumulation rate can provide an estimate for the fractional contribution of $\mathrm{N}_{2} \mathrm{O}_{5}$ uptake to total particulate nitrate production in the SLV. Direct comparison is difficult, however, as the $24 \mathrm{~h}$ ground-based accumulation rate includes contributions from photochemistry and nocturnal formation in the RL and nocturnal boundary layer (NBL) and is impacted by dilution and mixing processes. For example, the amount of nocturnally produced nitrate at the surface will depend on mixing between the NBL and RL during morning boundary layer expansion (Fig. 2). In Fig. 10a, the median base case prediction without dilution or mixing (gray, $8.6 \mu \mathrm{g} \mathrm{m}^{-3}$ per night) was nearly twice as large as the $24 \mathrm{~h}$ average accumulation rate observed at the surface during the same event $\left(4.6 \mu \mathrm{g} \mathrm{m}^{-3}\right.$ per night, red). Therefore, to more directly compare box model predictions and groundbased observations, Fig. 10a also shows the results from two simulations that include upper- and lower-limit estimates of loss from nocturnal and daytime dilution. For both scenarios,

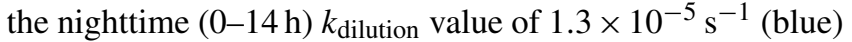
was applied to all modeled species as described above. At sunrise, morning mixing between the NBL (taken as $40 \%$ by volume) and RL (taken as $60 \%$ by volume) was then estimated using the assumed volume ratio between the two layers and assuming either equivalent nocturnal nitrate production in both layers (upper limit) or no production in the NBL (lower limit). Nocturnal production in the NBL is expected to be suppressed relative to the RL due to $\mathrm{O}_{3}$ titration (e.g., Fig. 6 here and Fig. S6 in Womack et al., 2019), making the assumption of equivalence an upper-limit estimate to nocturnally produced nitrate at the surface after morning mixing. The upper-limit case required no reduction of the model-predicted nitrate concentrations at sunrise (e.g., Fig. 9), whereas these concentrations were instantaneously reduced by $40 \%$ for the lower-limit case. To account for daytime dilution in the remaining $\sim 10 \mathrm{~h}$, morning concentrations for both cases were further diluted with the daytime boundary dilution rate constant from Womack et al. (2019) $\left(8 \times 10^{-6} \mathrm{~s}^{-1}\right)$, described above and in Sect. S1.4.1. For a single $24 \mathrm{~h}$ period, this resulted in a net median of 2.4 to $3.9 \mathrm{\mu g} \mathrm{m}^{-3}$ nitrate produced from nocturnal heterogeneous $\mathrm{N}_{2} \mathrm{O}_{5}$ uptake for the lower and upper-limit cases, respectively. When considering the entire possible range of dilution rate constants from Womack et al. (2019), the median values from both cases were between 1.1 and $4.2 \mu \mathrm{g} \mathrm{m}^{-3} \mathrm{~d}^{-1}$, as shown in Fig. S7.

Comparison of modeled rates to the observed surface buildup of $4.6 \mu \mathrm{g} \mathrm{m}^{-3} \mathrm{~d}^{-1}$ suggests that, on average, nitrate produced from heterogenous chemistry can account for at least $50 \%$ of the nitrate accumulation observed at the surface. This result is qualitatively consistent with an observational analysis by Pusede et al. (2016), who determined that nocturnal heterogeneous chemistry was the main source of regional aerosol nitrate during wintertime pollution events in the San Joaquin Valley. The lower-limit estimate, however, is also similar to a box model analysis of this same event by Womack et al. (2019), who found roughly equal contributions between photochemical and nocturnal nitrate production pathways, highlighting that photochemical nitrate production is also occurring during these events. Therefore, while results in Fig. 10a (including dilution) predict a median nocturnal fractional contribution of 52\%-85\% (ranging between $24 \%$ and $91 \%$; Fig. S7), confirmation and further quantification of this result will require additional, vertically resolved measurements of aerosol composition, gasphase precursors, and physical parameters, as well as more 

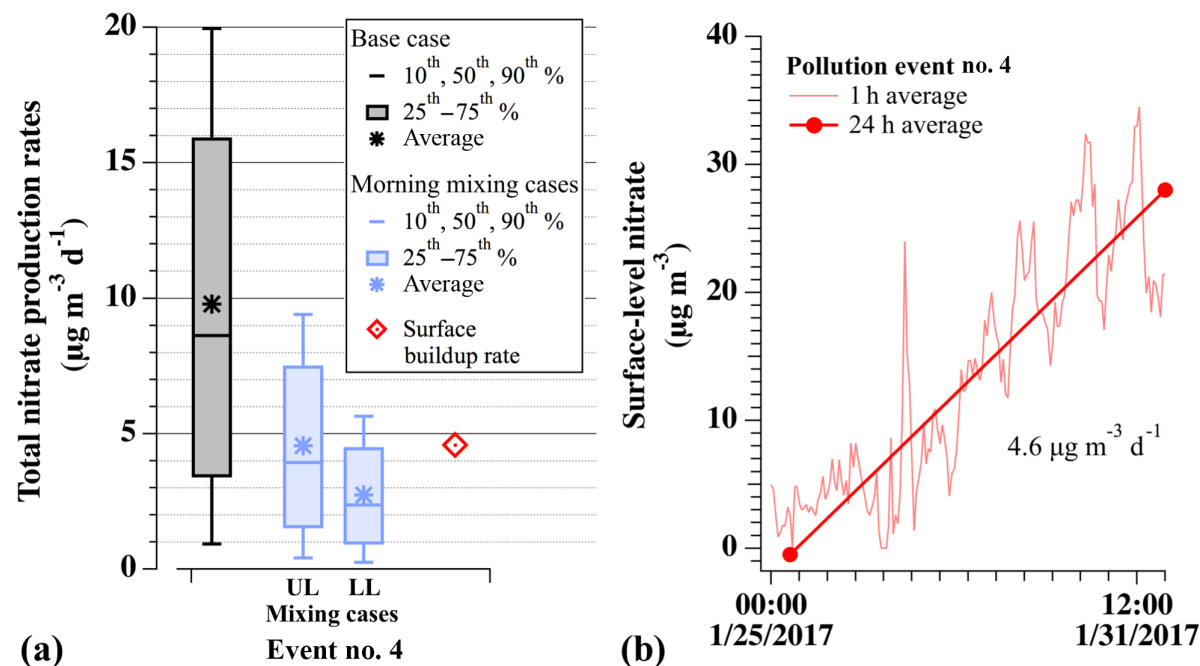

Figure 10. (a) For pollution event no. 4, comparison of model-predicted nocturnal nitrate production $\left(\mu \mathrm{g} \mathrm{m}^{-3} \mathrm{~d}^{-1}\right)$ for base case simulations (gray), simulations with $24 \mathrm{~h}$ of dilution (blue), and the average daily nitrate buildup observed at HW (red). Dilution cases are for simulations that incorporate nocturnal dilution rate constants of $1.2 \times 10^{-5}(\mathrm{~L}), 1.3 \times 10^{-5}(\mathrm{M})$, and $2.5 \times 10^{-5}(\mathrm{H}) \mathrm{s}^{-1}$, scaled by $60 \%$ during the day. Box-and-whisker plots show the 10th-90th percentile distributions of each set. Upper-limit (UL) values assume morning mixing between equivalent nitrate concentrations produced in the RL and NBL. Lower-limit (LL) values assume morning mixing with no nitrate production in the NBL. The red diamond shows the ground-based buildup rate, calculated from $24 \mathrm{~h}$ averaged data at HW in panel (b). (b) Observed concentrations and average daily buildup rate of nitrate aerosol mass (total mass $\cdot 0.58$ ) at HW during event no. 4.

sophisticated modeling of these multiday pollution accumulation events with 3-D chemical transport models.

\section{Summary and conclusions}

Aerosol- and gas-phase measurements collected during the 2017 UWFPS campaign showed multiple pollution events that exceeded $\mathrm{PM}_{2.5}$ standards in the SLV, the most populated region in the state of Utah. During these events, aerosol particles were largely composed of $\mathrm{NH}_{4} \mathrm{NO}_{3}$, which forms from the reaction between gas-phase $\mathrm{NH}_{3}$ and $\mathrm{HNO}_{3}$. While $\mathrm{NH}_{3}$ is emitted from surface sources, $\mathrm{HNO}_{3}$ is chemically formed from the oxidation of $\mathrm{NO}_{x}$ emissions. This oxidation can occur through daytime reactions with the photochemical $\mathrm{OH}$ radical or through nocturnal heterogeneous reactions involving $\mathrm{NO}_{3}$ and $\mathrm{N}_{2} \mathrm{O}_{5}$. The contribution of nocturnal chemistry to $\mathrm{PM}_{2.5}$ formation in the SLV is dependent on whether $\mathrm{NH}_{4} \mathrm{NO}_{3}$ formation is $\mathrm{NH}_{3}$ or $\mathrm{HNO}_{3}$ limited, as well as the $\mathrm{NO}_{3}$ production rate, $\mathrm{N}_{2} \mathrm{O}_{5}$ uptake efficiency, $\mathrm{ClNO}_{2}$ and $\mathrm{HNO}_{3}$ production yields, and loss processes such as air parcel dilution.

Vertically resolved measurements of gas- and particulatephase oxidized and reduced nitrogen in the SLV showed that $\mathrm{NH}_{4} \mathrm{NO}_{3}$ formation during pollution events was nearly always $\mathrm{HNO}_{3}$ limited but that oxidized and reduced nitrogen approached equivalence as pollution events progressed. This reagent balance analysis is consistent with aerosol thermodynamic modeling presented in Franchin et al. (2018), which predicted that all three major valleys in the Wasatch region were sensitive to nitrate reductions and that the SLV was also sensitive to $\mathrm{NH}_{3}$ reductions. Both observation- and modeling-based analyses agreed that $\mathrm{NH}_{4} \mathrm{NO}_{3}$ formation in the RL was largely $\mathrm{HNO}_{3}$ limited during pollution events, providing the possibility of a large contribution from nocturnal heterogeneous chemistry to $\mathrm{HNO}_{3}$ and $\mathrm{PM}_{2.5}$ mass.

Analysis of vertically resolved, calculated nitrate production rates (an upper-limit estimate due to heterogeneous $\mathrm{HNO}_{3}$ formation, $P_{\mathrm{NO}_{3}^{-} \text {,max }}$ ) and results from an observationally constrained chemical box model suggest that nocturnal chemistry is an efficient mechanism for $\mathrm{PM}_{2.5}$ production in the SLV during pollution events. Nitrate production rates had a median of $1.6 \mu \mathrm{g} \mathrm{m}^{-3} \mathrm{~h}^{-1}$, while values of $\gamma\left(\mathrm{N}_{2} \mathrm{O}_{5}\right)$ and $\varphi\left(\mathrm{ClNO}_{2}\right)$ had medians of 0.076 and 0.220 , respectively, during pollution events. Values of $\gamma\left(\mathrm{N}_{2} \mathrm{O}_{5}\right)$ were larger than previous field-based determinations (e.g., McDuffie et al., 2018b) and those predicted from the Bertram and Thornton (2009) parameterization but were in agreement with values derived using the $\mathrm{N}_{2} \mathrm{O}_{5}$ steady-state approach. The median $\varphi\left(\mathrm{ClNO}_{2}\right)$ value was larger than that derived from aircraft observations over the eastern US coast but was simultaneously overpredicted by $68 \%$ by the Bertram and Thornton (2009) parameterization, which uses measurements of aerosol chloride and aerosol water estimations.

While the box model has uncertainties associated with limited available measurements and model assumptions, the large measured aerosol SA, efficient $\mathrm{N}_{2} \mathrm{O}_{5}$ uptake coefficients, and moderate $\mathrm{ClNO}_{2}$ yields resulted in nightly modeled nitrate production rates that were largely insen- 
sitive to specific values of derived parameters. Agreement between base case modeled nightly nitrate production $\left(9.9 \mu \mathrm{g} \mathrm{m}^{-3}\right.$ per night) and that calculated from $P_{\mathrm{NO}_{3}^{-}, \max }$ values $\left(10.6 \mu \mathrm{g} \mathrm{m}^{-3}\right.$ per night) alternatively suggests that nitrate production is more sensitive to gas-phase $\mathrm{NO}_{2}$ oxidation rates than $\gamma\left(\mathrm{N}_{2} \mathrm{O}_{5}\right)$, providing confidence in the model's predictions of nocturnal nitrate. Of the parameters tested, the model was most sensitive to loss through air parcel dilution, with a $42 \%$ reduction to $5.7 \mu \mathrm{g} \mathrm{m}^{-3}$ nitrate per night when including a nocturnal $k_{\text {dilution }}$ rate constant of $1.3 \times 10^{-5} \mathrm{~s}^{-1}$. When considering the possible effects of $24 \mathrm{~h}$ dilution, model simulations predicted a reduced median of $2.4-3.9 \mu \mathrm{g} \mathrm{m}^{-3}$ nitrate $\mathrm{d}^{-1}$, corresponding to $52 \%-85 \%$ (median) of the net aerosol nitrate accumulation that was observed at a SLV ground site. Due to model uncertainties and sensitivities to dilution, further quantification of this result will require additional vertically resolved measurements and photochemical/3-D modeling analyses. These results, however, highlight the importance of nocturnal chemistry in the formation of $\mathrm{PM}_{2.5}$ in the SLV and can provide constraints for regulatory models of $\mathrm{PM}_{2.5}$ that are used to assess control strategies in this populated nonattainment area.

Code and data availability. Data from the UWFPS campaign can be found at the NOAA website: https://www.esrl.noaa.gov/csd/ field.html (last access: March 2019). Code written in IGOR Pro for the iterative box model can be found at https://esrl.noaa.gov/csd/ groups/csd7/measurements/2015winter/pubs/ (last access: March 2019). All referenced supplemental text, figures, and tables can be found in the Supplement.

Supplement. The supplement related to this article is available online at: https://doi.org/10.5194/acp-19-9287-2019-supplement.

Author contributions. During the UWFPS campaign, EEM, CCW, DLF, and WPD were responsible for the CRD gas-phase measurements; AF and AM for the AMS particle measurements; LG, BHL, and JAT for the $\mathrm{I}^{-}$ToF-CIMS measurements; and AM and JM for the $\mathrm{NH}_{3}$ instrument. MB and SSB organized the UWFPS campaign with technical support from WPD. EEM developed the box model code and preformed the analyses with support from CCW and SSB. EEM prepared the manuscript with contributions from coauthors.

Competing interests. The authors declare that they have no conflict of interest.

Acknowledgements. The authors would like to thank NOAA Aircraft Operations, staff, and pilots deployed as part of the UWFPS campaign, Jason Clark, Rob Mitchell, and Rob Militec.
Financial support. NOAA acknowledges support for Twin Otter flights from the Utah Division of Air Quality under agreement number 16-049696.

Review statement. This paper was edited by Yafang Cheng and reviewed by two anonymous referees.

\section{References}

Anttila, T., Kiendler-Scharr, A., Tillmann, R., and Mentel, T. F.: On the reactive uptake of gaseous compounds by organic-coated aqueous aerosols: Theoretical analysis and application to the heterogeneous hydrolysis of $\mathrm{N}_{2} \mathrm{O}_{5}$, J. Phys. Chem. A, 110, 1043510443, https://doi.org/10.1021/jp062403c, 2006.

Atkinson, R. and Arey, J.: Atmospheric degradation of volatile organic compounds, Chem. Rev., 103, 4605-4638, https://doi.org/10.1021/cr0206420, 2003.

Baasandorj, M., Hoch, S. W., Bares, R., Lin, J. C., Brown, S. S., Millet, D. B., Martin, R., Kelly, K., Zarzana, K. J., Whiteman, C. D., Dube, W. P., Tonnesen, G., Jaramillo, I. C., and Sohl, J.: Coupling between chemical and meteorological processes under persistent cold-air pool conditions: Evolution of wintertime $\mathrm{PM}_{2.5}$ pollution events and $\mathrm{N}_{2} \mathrm{O}_{5}$ observations in Utah's Salt Lake Valley, Environ. Sci. Technol., 51, 5941-5950, https://doi.org/10.1021/acs.est.6b06603, 2017.

Badger, C. L., Griffiths, P. T., George, I., Abbatt, J. P. D., and Cox, R. A.: Reactive uptake of $\mathrm{N}_{2} \mathrm{O}_{5}$ by aerosol particles containing mixtures of humic acid and ammonium sulfate, J. Phys. Chem. A, 110, 6986-6994, https://doi.org/10.1021/jp0562678, 2006.

Bahreini, R., Ervens, B., Middlebrook, A. M., Warneke, C., de Gouw, J. A., DeCarlo, P. F., Jimenez, J. L., Brock, C. A., Neuman, J. A., Ryerson, T. B., Stark, H., Atlas, E., Brioude, J., Fried, A., Holloway, J. S., Peischl, J., Richter, D., Walega, J., Weibring, P., Wollny, A. G., and Fehsenfeld, F. C.: Organic aerosol formation in urban and industrial plumes near Houston and Dallas, Texas, J. Geophys. Res.-Atmos., 114, D00F16, https://doi.org/10.1029/2008JD011493, 2009.

Beard, J. D., Beck, C., Graham, R., Packham, S. C., Traphagan, M., Giles, R. T., and Morgan, J. G.: Winter temperature inversions and emergency department visits for asthma in Salt Lake County, Utah, 2003-2008, Environ. Health Persp., 120, 13851390, https://doi.org/10.1289/ehp.1104349, 2012.

Behera, S. N., Sharma, M., Aneja, V. P., and Balasubramanian, R.: Ammonia in the atmosphere: a review on emission sources, atmospheric chemistry and deposition on terrestrial bodies, Environ. Sci. Pollut. R., 20, 8092-8131, https://doi.org/10.1007/s11356-013-2051-9, 2013.

Behnke, W., George, C., Scheer, V., and Zetzsch, C.: Production and decay of $\mathrm{ClNO}_{2}$ from the reaction of gaseous $\mathrm{N}_{2} \mathrm{O}_{5}$ with $\mathrm{NaCl}$ solution: Bulk and aerosol experiments, J. Geophys. Res.Atmos., 102, 3795-3804, https://doi.org/10.1029/96JD03057, 1997.

Bertram, T. H. and Thornton, J. A.: Toward a general parameterization of $\mathrm{N}_{2} \mathrm{O}_{5}$ reactivity on aqueous particles: the competing effects of particle liquid water, nitrate and chloride, Atmos. Chem. Phys., 9, 8351-8363, https://doi.org/10.5194/acp-9-8351-2009, 2009. 
Bertram, T. H., Thornton, J. A., Riedel, T. P., Middlebrook, A. M., Bahreini, R., Bates, T. S., Quinn, P. K., and Coffman, D. J.: Direct observations of $\mathrm{N}_{2} \mathrm{O}_{5}$ reactivity on ambient aerosol particles, Geophys. Res. Lett., 36, L19803, https://doi.org/10.1029/2009GL040248, 2009.

Brock, C. A., Cozic, J., Bahreini, R., Froyd, K. D., Middlebrook, A. M., McComiskey, A., Brioude, J., Cooper, O. R., Stohl, A., Aikin, K. C., de Gouw, J. A., Fahey, D. W., Ferrare, R. A., Gao, R.-S., Gore, W., Holloway, J. S., Hübler, G., Jefferson, A., Lack, D. A., Lance, S., Moore, R. H., Murphy, D. M., Nenes, A., Novelli, P. C., Nowak, J. B., Ogren, J. A., Peischl, J., Pierce, R. B., Pilewskie, P., Quinn, P. K., Ryerson, T. B., Schmidt, K. S., Schwarz, J. P., Sodemann, H., Spackman, J. R., Stark, H., Thomson, D. S., Thornberry, T., Veres, P., Watts, L. A., Warneke, C., and Wollny, A. G.: Characteristics, sources, and transport of aerosols measured in spring 2008 during the aerosol, radiation, and cloud processes affecting Arctic Climate (ARCPAC) Project, Atmos. Chem. Phys., 11, 24232453, https://doi.org/10.5194/acp-11-2423-2011, 2011.

Brock, C. A., Wagner, N. L., Anderson, B. E., Attwood, A. R., Beyersdorf, A., Campuzano-Jost, P., Carlton, A. G., Day, D. A., Diskin, G. S., Gordon, T. D., Jimenez, J. L., Lack, D. A., Liao, J., Markovic, M. Z., Middlebrook, A. M., Ng, N. L., Perring, A. E., Richardson, M. S., Schwarz, J. P., Washenfelder, R. A., Welti, A., Xu, L., Ziemba, L. D., and Murphy, D. M.: Aerosol optical properties in the southeastern United States in summer - Part 1: Hygroscopic growth, Atmos. Chem. Phys., 16, 49875007, https://doi.org/10.5194/acp-16-4987-2016, 2016.

Brown, S. G., Hyslop, N. P., Roberts, P. T., McCarthy, M. C., and Lurmann, F. W.: Wintertime Vertical Variations in Particulate Matter (PM) and Precursor Concentrations in the San Joaquin Valley during the California Regional Coarse PM/Fine PM Air Quality Study, J. Air Waste Manage., 56, 1267-1277, https://doi.org/10.1080/10473289.2006.10464583, 2006.

Brown, S. S. and Stutz, J.: Nighttime radical observations and chemistry, Chem. Soc. Rev., 41, 6405-6447, https://doi.org/10.1039/c2cs35181a, 2012.

Brown, S. S., Stark, H., and Ravishankara, A. R.: Applicability of the steady state approximation to the interpretation of atmospheric observations of $\mathrm{NO}_{3}$ and $\mathrm{N}_{2} \mathrm{O}_{5}$, J. Geophys. Res., 108, 4539, https://doi.org/10.1029/2003jd003407, 2003.

Brown, S. S., Dibb, J. E., Stark, H., Aldener, M., Vozella, M., Whitlow, S., Williams, E. J., Lerner, B. M., Jakoubek, R., Middlebrook, A. M., DeGouw, J. A., Warneke, C., Goldan, P. D., Kuster, W. C., Angevine, W. M., Sueper, D. T., Quinn, P. K., Bates, T. S., Meagher, J. F., Fehsenfeld, F. C., and Ravishankara, A. R.: Nighttime removal of $\mathrm{NO}_{x}$ in the summer marine boundary layer, Geophys. Res. Lett., 31, L07108, https://doi.org/10.1029/2004gl019412, 2004.

Brown, S. S., Osthoff, H. D., Stark, H., Dubé, W. P., Ryerson, T. B., Warneke, C., de Gouw, J. A., Wollny, A. G., Parrish, D. D., Fehsenfeld, F. C., and Ravishankara, A. R.: Aircraft observations of daytime $\mathrm{NO}_{3}$ and $\mathrm{N}_{2} \mathrm{O}_{5}$ and their implications for tropospheric chemistry, J. Photoch. Photobio. A, 176, 270-278, https://doi.org/10.1016/j.jphotochem.2005.10.004, 2005.

Brown, S. S., Dubé, W. P., Osthoff, H. D., Stutz, J., Ryerson, T. B., Wollny, A. G., Brock, C. A., Warneke, C., de Gouw, J. A., Atlas, E., Neuman, J. A., Holloway, J. S., Lerner, B. M., Williams, E. J., Kuster, W. C., Goldan, P. D., Angevine, W. M.,
Trainer, M., Fehsenfeld, F. C., and Ravishankara, A. R.: Vertical profiles in $\mathrm{NO}_{3}$ and $\mathrm{N}_{2} \mathrm{O}_{5}$ measured from an aircraft: Results from the NOAA P-3 and surface platforms during the New England Air Quality Study 2004, J. Geophys. Res., 112, D22304, https://doi.org/10.1029/2007jd008883, 2007.

Brown, S. S., Dubé, W. P., Fuchs, H., Ryerson, T. B., Wollny, A. G., Brock, C. A., Bahreini, R., Middlebrook, A. M., Neuman, J. A., Atlas, E., Roberts, J. M., Osthoff, H. D., Trainer, M., Fehsenfeld, F. C., and Ravishankara, A. R.: Reactive uptake coefficients for $\mathrm{N}_{2} \mathrm{O}_{5}$ determined from aircraft measurements during the Second Texas Air Quality Study: Comparison to current model parameterizations, J. Geophys. Res.-Atmos., 114, D00F10, https://doi.org/10.1029/2008JD011679, 2009.

Brown, S. S., Dubé, W. P., Tham, Y. J., Zha, Q., Xue, L., Poon, S., Wang, Z., Blake, D. R., Tsui, W., Parrish, D. D., and Wang, T.: Nighttime chemistry at a high altitude site above Hong Kong, J. Geophys. Res.-Atmos., 121, 2457-2475, https://doi.org/10.1002/2015JD024566, 2016.

Canagaratna, M. R., Jimenez, J. L., Kroll, J. H., Chen, Q., Kessler, S. H., Massoli, P., Hildebrandt Ruiz, L., Fortner, E., Williams, L. R., Wilson, K. R., Surratt, J. D., Donahue, N. M., Jayne, J. T., and Worsnop, D. R.: Elemental ratio measurements of organic compounds using aerosol mass spectrometry: characterization, improved calibration, and implications, Atmos. Chem. Phys., 15, 253-272, https://doi.org/10.5194/acp-15-253-2015, 2015.

Cerully, K. M., Bougiatioti, A., Hite Jr., J. R., Guo, H., Xu, L., $\mathrm{Ng}, \mathrm{N}$. L., Weber, R., and Nenes, A.: On the link between hygroscopicity, volatility, and oxidation state of ambient and water-soluble aerosols in the southeastern United States, Atmos. Chem. Phys., 15, 8679-8694, https://doi.org/10.5194/acp15-8679-2015, 2015.

Chen, L.-W. A., Watson, J. G., Chow, J. C., Green, M. C., Inouye, D., and Dick, K.: Wintertime particulate pollution episodes in an urban valley of the Western US: a case study, Atmos. Chem. Phys., 12, 10051-10064, https://doi.org/10.5194/acp-12-100512012, 2012.

Cosman, L. M., Knopf, D. A., and Bertram, A. K.: $\mathrm{N}_{2} \mathrm{O}_{5}$ reactive uptake on aqueous sulfuric acid solutions coated with branched and straight-chain insoluble organic surfactants, J. Phys. Chem. A, 112, 2386-2396, https://doi.org/10.1021/jp710685r, 2008.

Ellis, R. A., Murphy, J. G., Pattey, E., van Haarlem, R., O’Brien, J. M., and Herndon, S. C.: Characterizing a Quantum Cascade Tunable Infrared Laser Differential Absorption Spectrometer (QC-TILDAS) for measurements of atmospheric ammonia, Atmos. Meas. Tech., 3, 397-406, https://doi.org/10.5194/amt-3397-2010, 2010.

Environmental Protection Agency: Ambinet Monitoring Technology Information Center, available at: https://www.epa.gov/amtic, last access: September 2018.

Folkers, M., Mentel, T. F., and Wahner, A.: Influence of an organic coating on the reactivity of aqueous aerosols probed by the heterogeneous hydrolysis of $\mathrm{N}_{2} \mathrm{O}_{5}$, Geophys. Res. Lett., 30, 1644, https://doi.org/10.1029/2003GL017168, 2003.

Franchin, A., Fibiger, D. L., Goldberger, L., McDuffie, E. E., Moravek, A., Womack, C. C., Crosman, E. T., Docherty, K. S., Dube, W. P., Hoch, S. W., Lee, B. H., Long, R., Murphy, J. G., Thornton, J. A., Brown, S. S., Baasandorj, M., and Middlebrook, A. M.: Airborne and ground-based observations of ammoniumnitrate-dominated aerosols in a shallow boundary layer during in- 
tense winter pollution episodes in northern Utah, Atmos. Chem. Phys., 18, 17259-17276, https://doi.org/10.5194/acp-18-172592018, 2018.

Fried, A., Henry, B. E., Calvert, J. G., and Mozurkewich, M.: The reaction probability of $\mathrm{N}_{2} \mathrm{O}_{5}$ with sulfuric acid aerosols at stratospheric temperatures and compositions, J. Geophys. Res.Atmos., 99, 3517-3532, https://doi.org/10.1029/93JD01907, 1994.

Fuchs, H., Dube, W. P., Lerner, B. M., Wagner, N. L., Williams, E. J., and Brown, S. S.: A sensitive and versatile detector for atmospheric $\mathrm{NO}_{2}$ and $\mathrm{NO}_{x}$ based on blue diode laser cavity ring-down spectroscopy, Environ. Sci. Technol., 43, 7831-7836, https://doi.org/10.1021/es902067h, 2009.

Gillies, R. R., Wang, S.-Y., and Booth, M. R.: Atmospheric Scale Interaction on Wintertime Intermountain West Low-Level Inversions, Weather Forecast., 25, 1196-1210, https://doi.org/10.1175/2010WAF2222380.1, 2010.

Green, M. C., Chow, J. C., Watson, J. G., Dick, K., and Inouye, D.: Effects of Snow Cover and Atmospheric Stability on Winter $\mathrm{PM}_{2.5}$ Concentrations in Western U.S. Valleys, J. Appl. Meteorol. Clim., 54, 1191-1201, https://doi.org/10.1175/JAMC-D-140191.1, 2015.

Griffiths, P. T., Badger, C. L., Cox, R. A., Folkers, M., Henk, H. H., and Mentel, T. F.: Reactive uptake of $\mathrm{N}_{2} \mathrm{O}_{5}$ by aerosols containing dicarboxylic acids. Effect of particle phase, composition, and nitrate content, J. Phys. Chem. A, 113, 5082-5090, https://doi.org/10.1021/jp8096814, 2009.

Hansen, J. C., Woolwine Iii, W. R., Bates, B. L., Clark, J. M., Kuprov, R. Y., Mukherjee, P., Murray, J. A., Simmons, M. A., Waite, M. F., Eatough, N. L., Eatough, D. J., Long, R., and Grover, B. D.: Semicontinuous $\mathrm{PM}_{2.5}$ and $\mathrm{PM}_{10}$ Mass and Composition Measurements in Lindon, Utah, during Winter 2007, J. Air Waste Manage., 60, 346-355, https://doi.org/10.3155/10473289.60.3.346, 2010.

IUPAC: Data Sheet NOx28, available at: http://iupac.pole-ether.fr/ htdocs/datasheets/pdf/NOx28_NO2_O3.pdf (last access: March 2018), 2008.

Jimenez, J. L., Canagaratna, M. R., Donahue, N. M., Prevot, A. S. H., Zhang, Q., Kroll, J. H., DeCarlo, P. F., Allan, J. D., Coe, H., Ng, N. L., Aiken, A. C., Docherty, K. S., Ulbrich, I. M., Grieshop, A. P., Robinson, A. L., Duplissy, J., Smith, J. D., Wilson, K. R., Lanz, V. A., Hueglin, C., Sun, Y. L., Tian, J., Laaksonen, A., Raatikainen, T., Rautiainen, J., Vaattovaara, P., Ehn, M., Kulmala, M., Tomlinson, J. M., Collins, D. R., Cubison, M. J., Dunlea, J., Huffman, J. A., Onasch, T. B., Alfarra, M. R., Williams, P. I., Bower, K., Kondo, Y., Schneider, J., Drewnick, F., Borrmann, S., Weimer, S., Demerjian, K., Salcedo, D., Cottrell, L., Griffin, R., Takami, A., Miyoshi, T., Hatakeyama, S., Shimono, A., Sun, J. Y., Zhang, Y. M., Dzepina, K., Kimmel, J. R., Sueper, D., Jayne, J. T., Herndon, S. C., Trimborn, A. M., Williams, L. R., Wood, E. C., Middlebrook, A. M., Kolb, C. E., Baltensperger, U., and Worsnop, D. R.: Evolution of organic aerosols in the atmosphere, Science, 326, 1525, https://doi.org/10.1126/science.1180353, 2009.

Kelly, K. E., Kotchenruther, R., Kuprov, R., and Silcox, G. D.: Receptor model source attributions for Utah's Salt Lake City airshed and the impacts of wintertime secondary ammonium nitrate and ammonium chloride aerosol, J. Air Waste Manage., 63, 575590, https://doi.org/10.1080/10962247.2013.774819, 2013.
Kenagy, H. S., Sparks, T. L., Ebben, C. J., Wooldridge, P. J., Lopez-Hilfiker, F. D., Lee, B. H., Thornton, J. A., McDuffie, E. E., Fibiger, D. L., Brown, S. S., Montzka, D. D., Weinheimer, A. J., Schroder, J. C., Campuzano-Jost, P., Day, D. A., Jimenez, J. L., Dibb, J., Apel, E., Campos, T., Shah, V., Jaegle, L., and Cohen, R. C.: $\mathrm{NO}_{x}$ Lifetime and $\mathrm{NO}_{y}$ Partitioning During WINTER, J. Geophys. Res.-Atmos., 123, 9813-9827, https://doi.org/10.1029/2018JD028736, 2018.

Kuprov, R., Eatough, D. J., Cruickshank, T., Olson, N., Cropper, P. M., and Hansen, J. C.: Composition and secondary formation of fine particulate matter in the Salt Lake Valley: Winter 2009, J. Air Waste Manage., 64, 957-969, https://doi.org/10.1080/10962247.2014.903878, 2014.

Kuwata, M., Zorn, S. R., and Martin, S. T.: Using Elemental Ratios to Predict the Density of Organic Material Composed of Carbon, Hydrogen, and Oxygen, Environ. Sci. Technol., 46, 787794, https://doi.org/10.1021/es202525q, 2012.

Lee, B. H., Lopez-Hilfiker, F. D., Mohr, C., Kurtén, T., Worsnop, D. R., and Thornton, J. A.: An iodide-adduct high-resolution timeof-flight chemical-ionization mass spectrometer: Application to atmospheric inorganic and organic compounds, Environ. Sci. Technol., 48, 6309-6317, https://doi.org/10.1021/es500362a, 2014.

Lee, B. H., Lopez-Hilfiker, F. D., Veres, P. R., McDuffie, E. E., Fibiger, D. L., Sparks, T. L., Ebben, C. J., Green, J. R., Schroder, J. C., Campuzano-Jost, P., Iyer, S., D'Ambro, E. L., Schobesberger, S., Brown, S. S., Wooldridge, P. J., Cohen, R. C., Fiddler, M. N., Bililign, S., Jimenez, J. L., Kurtén, T., Weinheimer, A. J., Jaegle, L., and Thornton, J. A.: Flight Deployment of a High-Resolution Time-of-Flight Chemical Ionization Mass Spectrometer: Observations of Reactive Halogen and Nitrogen Oxide Species, J. Geophys. Res.-Atmos., 123, 7670 7686, https://doi.org/10.1029/2017JD028082, 2018.

Lelieveld, J. and Crutzen, P. J.: Influences of cloud photochemical processes on tropospheric ozone, Nature, 343, 227-233, 1990.

Livingston, C., Rieger, P., and Winer, A.: Ammonia emissions from a representative in-use fleet of light and medium-duty vehicles in the California South Coast Air Basin, Atmos. Environ., 43, 3326-3333, https://doi.org/10.1016/j.atmosenv.2009.04.009, 2009.

Long, R. W., Eatough, N. L., Mangelson, N. F., Thompson, W., Fiet, K., Smith, S., Smith, R., Eatough, D. J., Pope, C. A., and Wilson, W. E.: The measurement of $\mathrm{PM}_{2.5}$, including semivolatile components, in the EMPACT program: results from the Salt Lake City Study, Atmos. Environ., 37, 4407-4417, https://doi.org/10.1016/S1352-2310(03)00585-5, 2003.

Long, R. W., Eatough, N. L., Eatough, D. J., Meyer, M. B., and Wilson, W. E.: Continuous Determination of Fine Particulate Matter Mass in the Salt Lake City Environmental Monitoring Project: A Comparison of Real-Time and Conventional TEOM Monitor Results, J. Air Waste Manage., 55, 1782-1796, https://doi.org/10.1080/10473289.2005.10464776, 2005a.

Long, R. W., Modey, W. K., Smith, P. S., Smith, R., Merrill, C., Pratt, J., Stubbs, A., Eatough, N. L., Eatough, D. J., Malm, W. C., and Wilson, W. E.: One- and Three-Hour PM 2.5 Characterization, Speciation, and Source Apportionment Using Continuous and Integrated Samplers, Aerosol Sci. Tech., 39, 238-248, https://doi.org/10.1080/027868290925633, 2005b. 
Macintyre, H. L. and Evans, M. J.: Sensitivity of a global model to the uptake of $\mathrm{N}_{2} \mathrm{O}_{5}$ by tropospheric aerosol, Atmos. Chem. Phys., 10, 7409-7414, https://doi.org/10.5194/acp10-7409-2010, 2010.

Malek, E., Davis, T., Martin, R. S., and Silva, P. J.: Meteorological and environmental aspects of one of the worst national air pollution episodes (January, 2004) in Logan, Cache Valley, Utah, USA, Atmos. Res., 79, 108-122, https://doi.org/10.1016/j.atmosres.2005.05.003, 2006.

Mangelson, N. F., Lewis, L., Joseph, J. M., Cui, W., Machir, J., Eatough, D. J., Rees, L. B., Wilkerson, T., and Jensen, D. T.: The contribution of sulfate and nitrate to atmospheric fine particles during winter inversion fogs in Cache Valley, Utah, J. Air Waste Manage., 47, 167-175, https://doi.org/10.1080/10473289.1997.10464429, 1997.

Martin, R.: Cache Valley Air Quality Studies, available at: http://citeseerx.ist.psu.edu/viewdoc/download?doi=10.1.1.127. 8179\&rep=rep1\&type=pdf (last access: April 2018), 2006.

McDuffie, E. E., Fibiger, D. L., Dubé, W. P., Lopez Hilfiker, F., Lee, B. H., Jaeglé, L., Guo, H., Weber, R. J., Reeves, J. M., Weinheimer, A. J., Schroder, J. C., Campuzano-Jost, P., Jimenez, J. L., Dibb, J. E., Veres, P., Ebben, C., Sparks, T. L., Wooldridge, P. J., Cohen, R. C., Campos, T., Hall, S. R., Ullmann, K., Roberts, J. M., Thornton, J. A., and Brown, S. S.: $\mathrm{ClNO}_{2}$ Yields From Aircraft Measurements During the 2015 WINTER Campaign and Critical Evaluation of the Current Parameterization, J. Geophys. Res.-Atmos., 123, 12994-13015, https://doi.org/10.1029/2018JD029358, 2018a.

McDuffie, E. E., Fibiger, D. L., Dubé, W. P., Lopez-Hilfiker, F., Lee, B. H., Thornton, J. A., Shah, V., Jaegle, L., Guo, H., Weber, R. J., Reeves, J. M., Weinheimer, A. J., Schroder, J. C., CampuzanoJost, P., Jimenez, J. L., Dibb, J. E., Veres, P., Ebben, C., Sparks, T. L., Wooldridge, P. J., Cohen, R. C., Hornbrook, R. S., Apel, E. C., Campos, T., Hall, S. R., Ullmann, K., and Brown, S. S.: Heterogeneous $\mathrm{N}_{2} \mathrm{O}_{5}$ uptake during winter: Aircraft measurements during the 2015 WINTER campaign and critical evaluation of current parameterizations, J. Geophys. Res.-Atmos., 123, 43454372, https://doi.org/10.1002/2018JD028336, 2018b.

McNeill, V. F., Patterson, J., Wolfe, G. M., and Thornton, J. A.: The effect of varying levels of surfactant on the reactive uptake of $\mathrm{N}_{2} \mathrm{O}_{5}$ to aqueous aerosol, Atmos. Chem. Phys., 6, 1635-1644, https://doi.org/10.5194/acp-6-1635-2006, 2006.

Mei, F., Hayes, P. L., Ortega, A., Taylor, J. W., Allan, J. D., Gilman, J., Kuster, W., de Gouw, J., Jimenez, J. L., and Wang, J.: Droplet activation properties of organic aerosols observed at an urban site during CalNex-LA, J. Geophys. Res.-Atmos., 118, 2903-2917, https://doi.org/10.1002/jgrd.50285, 2013.

Mentel, T., F, Sohn, M., and Wahner, A.: Nitrate effect in the heterogeneous hydrolysis of dinitrogen pentoxide on aqueous aerosols, Phys. Chem. Chem. Phys., 1, 5451-5457, https://doi.org/10.1039/A905338G, 1999.

Middlebrook, A. M., Bahreini, R., Jimenez, J. L., and Canagaratna, M. R.: Evaluation of Composition-Dependent Collection Efficiencies for the Aerodyne Aerosol Mass Spectrometer using Field Data, Aerosol Sci. Tech., 46, 258-271, https://doi.org/10.1080/02786826.2011.620041, 2012.

Mielke, L. H., Furgeson, A., and Osthoff, H. D.: Observation of $\mathrm{ClNO}_{2}$ in a Mid-Continental Urban Environment, Environ. Sci.
Technol., 45, 8889-8896, https://doi.org/10.1021/es201955u, 2011.

Mielke, L. H., Stutz, J., Tsai, C., Hurlock, S. C., Roberts, J. M., Veres, P. R., Froyd, K. D., Hayes, P. L., Cubison, M. J., Jimenez, J. L., Washenfelder, R. A., Young, C. J., Gilman, J. B., de Gouw, J. A., Flynn, J. H., Grossberg, N., Lefer, B. L., Liu, J., Weber, R. J., and Osthoff, H. D.: Heterogeneous formation of nitryl chloride and its role as a nocturnal $\mathrm{NO}_{x}$ reservoir species during CalNex-LA 2010, J. Geophys. Res.-Atmos., 118, 10638-10652, https://doi.org/10.1002/jgrd.50783, 2013.

Mielke, L. H., Furgeson, A., Odame-Ankrah, C. A., and Osthoff, H. D.: Ubiquity of $\mathrm{ClNO}_{2}$ in the urban boundary layer of Calgary, Alberta, Canada, Can. J. Chem., 94, 414-423, https://doi.org/10.1139/cjc-2015-0426, 2016.

Moravek, A., Murphy, J. G., Hrdina, A., Lin, J. C., Pennell, C., Franchin, A., Middlebrook, A. M., Fibiger, D. L., Womack, C. C., McDuffie, E. E., Martin, R., Moore, K., Baasandorj, M., and Brown, S. S.: Wintertime Spatial Distribution of Ammonia and its Emission Sources in the Great Salt Lake Region, Atmos. Chem. Phys. Discuss., https://doi.org/10.5194/acp-2019-266, in review, 2019.

Morgan, W. T., Ouyang, B., Allan, J. D., Aruffo, E., Di Carlo, P., Kennedy, O. J., Lowe, D., Flynn, M. J., Rosenberg, P. D., Williams, P. I., Jones, R., McFiggans, G. B., and Coe, H.: Influence of aerosol chemical composition on $\mathrm{N}_{2} \mathrm{O}_{5}$ uptake: airborne regional measurements in northwestern Europe, Atmos. Chem. Phys., 15, 973-990, https://doi.org/10.5194/acp-15-9732015, 2015.

Mozurkewich, M.: The dissociation constant of ammonium nitrate and its dependence on temperature, relative humidity and particle size, Atmos. Environ. A-Gen., 27, 261-270, https://doi.org/10.1016/0960-1686(93)90356-4, 1993.

Nowak, J. B., Neuman, J. A., Bahreini, R., Middlebrook, A. M., Holloway, J. S., McKeen, S. A., Parrish, D. D., Ryerson, T. B., and Trainer, M.: Ammonia sources in the California South Coast Air Basin and their impact on ammonium nitrate formation, Geophys. Res. Lett., 39, L07804, https://doi.org/10.1029/2012GL051197, 2012.

Osthoff, H. D., Roberts, J. M., Ravishankara, A. R., Williams, E. J., Lerner, B. M., Sommariva, R., Bates, T. S., Coffman, D., Quinn, P. K., Dibb, J. E., Stark, H., Burkholder, J. B., Talukdar, R. K., Meagher, J., Fehsenfeld, F. C., and Brown, S. S.: High levels of nitryl chloride in the polluted subtropical marine boundary layer, Nat. Geosci., 1, 324-328, https://doi.org/10.1038/ngeo177, 2008.

Phillips, G. J., Thieser, J., Tang, M., Sobanski, N., Schuster, G., Fachinger, J., Drewnick, F., Borrmann, S., Bingemer, H., Lelieveld, J., and Crowley, J. N.: Estimating $\mathrm{N}_{2} \mathrm{O}_{5}$ uptake coefficients using ambient measurements of $\mathrm{NO}_{3}, \mathrm{~N}_{2} \mathrm{O}_{5}, \mathrm{ClNO}_{2}$ and particle-phase nitrate, Atmos. Chem. Phys., 16, 13231-13249, https://doi.org/10.5194/acp-16-13231-2016, 2016.

Pope, C. A., Muhlestein, J. B., May, H. T., Renlund, D. G., Anderson, J. L., and Horne, B. D.: Ischemic Heart Disease Events Triggered by Short-Term Exposure to Fine Particulate Air Pollution, Circulation, 114, 2443-2448, https://doi.org/10.1161/CIRCULATIONAHA.106.636977, 2006.

Pope, C. A., Muhlestein, J. B., Anderson, J. L., Cannon, J. B., Hales, N. M., Meredith, K. G., Le, V., and Horne, B. D.: 
Short-Term Exposure to Fine Particulate Matter Air Pollution Is Preferentially Associated With the Risk of ST-Segment Elevation Acute Coronary Events, J. Am. Heart Assoc., 4, https://doi.org/10.1161/JAHA.115.002506, 2015.

Prabhakar, G., Parworth, C. L., Zhang, X., Kim, H., Young, D. E., Beyersdorf, A. J., Ziemba, L. D., Nowak, J. B., Bertram, T. H., Faloona, I. C., Zhang, Q., and Cappa, C. D.: Observational assessment of the role of nocturnal residuallayer chemistry in determining daytime surface particulate nitrate concentrations, Atmos. Chem. Phys., 17, 14747-14770, https://doi.org/10.5194/acp-17-14747-2017, 2017.

Pusede, S. E., Duffey, K. C., Shusterman, A. A., Saleh, A., Laughner, J. L., Wooldridge, P. J., Zhang, Q., Parworth, C. L., Kim, H., Capps, S. L., Valin, L. C., Cappa, C. D., Fried, A., Walega, J., Nowak, J. B., Weinheimer, A. J., Hoff, R. M., Berkoff, T. A., Beyersdorf, A. J., Olson, J., Crawford, J. H., and Cohen, R. C.: On the effectiveness of nitrogen oxide reductions as a control over ammonium nitrate aerosol, Atmos. Chem. Phys., 16, 25752596, https://doi.org/10.5194/acp-16-2575-2016, 2016.

Reeves, H. D. and Stensrud, D. J.: Synoptic-Scale Flow and Valley Cold Pool Evolution in the Western United States, Weather Forecast., 24, 1625-1643, https://doi.org/10.1175/2009WAF2222234.1, 2009.

Riedel, T. P., Bertram, T. H., Ryder, O. S., Liu, S., Day, D. A., Russell, L. M., Gaston, C. J., Prather, K. A., and Thornton, J. A.: Direct $\mathrm{N}_{2} \mathrm{O}_{5}$ reactivity measurements at a polluted coastal site, Atmos. Chem. Phys., 12, 2959-2968, https://doi.org/10.5194/acp12-2959-2012, 2012.

Riedel, T. P., Wagner, N. L., Dubé, W. P., Middlebrook, A. M., Young, C. J., Öztürk, F., Bahreini, R., VandenBoer, T. C., Wolfe, D. E., Williams, E. J., Roberts, J. M., Brown, S. S., and Thornton, J. A.: Chlorine activation within urban or power plant plumes: Vertically resolved $\mathrm{ClNO}_{2}$ and $\mathrm{Cl}_{2}$ measurements from a tall tower in a polluted continental setting, J. Geophys. Res.-Atmos., 118, 8702-8715, https://doi.org/10.1002/jgrd.50637, 2013.

Riemer, N., Vogel, H., Vogel, B., Schell, B., Ackermann, I., Kessler, C., and Hass, H.: Impact of the heterogeneous hydrolysis of $\mathrm{N}_{2} \mathrm{O}_{5}$ on chemistry and nitrate aerosol formation in the lower troposphere under photosmog conditions, J. Geophys. Res.-Atmos., 108, 4144, https://doi.org/10.1029/2002JD002436, 2003.

Riemer, N., Vogel, H., Vogel, B., Anttila, T., Kiendler-Scharr, A., and Mentel, T. F.: Relative importance of organic coatings for the heterogeneous hydrolysis of $\mathrm{N}_{2} \mathrm{O}_{5}$ during summer in Europe, J. Geophys. Res.-Atmos., 114, D17307, https://doi.org/10.1029/2008JD011369, 2009.

Ryder, O. S., Campbell, N. R., Shaloski, M., Al-Mashat, H., Nathanson, G. M., and Bertram, T. H.: Role of organics in regulating $\mathrm{ClNO}_{2}$ production at the air-sea interface, J. Phys. Chem. A, 119, 8519-8526, https://doi.org/10.1021/jp5129673, 2015.

Sarwar, G., Simon, H., Xing, J., and Mathur, R.: Importance of tropospheric $\mathrm{ClNO}_{2}$ chemistry across the Northern Hemisphere, Geophys. Res. Lett., 41, 4050-4058, https://doi.org/10.1002/2014g1059962, 2014.

Shah, V., Jaeglé, L., Thornton, J. A., Lopez-Hilfiker, F. D., Lee, B. H., Schroder, J. C., Campuzano-Jost, P., Jimenez, J. L., Guo, H., Sullivan, A. P., Weber, R. J., Green, J. R., Fiddler, M. N., Bililign, S., Campos, T. L., Stell, M., Weinheimer, A. J., Montzka, D. D., and Brown, S. S.: Chemical feedbacks weaken the wintertime re- sponse of particulate sulfate and nitrate to emissions reductions over the eastern United States, P. Natl. Acad. Sci. USA, 115, 8110-8115, https://doi.org/10.1073/pnas.1803295115, 2018.

Shetter, R. E. and Müller, M.: Photolysis frequency measurements using actinic flux spectroradiometry during the PEM-Tropics mission: Instrumentation description and some results, J. Geophys. Res.-Atmos., 104, 5647-5661, https://doi.org/10.1029/98JD01381, 1999.

Shingler, T., Crosbie, E., Ortega, A., Shiraiwa, M., Zuend, A., Beyersdorf, A., Ziemba, L., Anderson, B., Thornhill, L., Perring, A. E., Schwarz, J. P., Campazano-Jost, P., Day, D. A., Jimenez, J. L., Hair, J. W., Mikoviny, T., Wisthaler, A., and Sorooshian, A.: Airborne characterization of subsaturated aerosol hygroscopicity and dry refractive index from the surface to $6.5 \mathrm{~km}$ during the SEAC4RS campaign, J. Geophys. Res.-Atmos., 121, 4188-4210, https://doi.org/10.1002/2015JD024498, 2016.

Silcox, G. D., Kelly, K. E., Crosman, E. T., Whiteman, C. D., and Allen, B. L.: Wintertime $\mathrm{PM}_{2.5}$ concentrations during persistent, multi-day cold-air pools in a mountain valley, Atmos. Environ., 46, 17-24, https://doi.org/10.1016/j.atmosenv.2011.10.041, 2012.

Silva, P. J., Vawdrey, E. L., Corbett, M., and Erupe, M.: Fine particle concentrations and composition during wintertime inversions in Logan, Utah, USA, Atmos. Environ., 41, 5410-5422, https://doi.org/10.1016/j.atmosenv.2007.02.016, 2007.

Stutz, J., Alicke, B., Ackermann, R., Geyer, A., White, A., and Williams, E.: Vertical profiles of $\mathrm{NO}_{3}, \mathrm{~N}_{2} \mathrm{O}_{5}, \mathrm{O}_{3}$, and $\mathrm{NO}_{x}$ in the nocturnal boundary layer: 1. Observations during the Texas Air Quality Study 2000, J. Geophys. Res.-Atmos., 109, https://doi.org/10.1029/2003JD004209, 2004.

Tham, Y. J., Wang, Z., Li, Q., Wang, W., Wang, X., Lu, K., Ma, N., Yan, C., Kecorius, S., Wiedensohler, A., Zhang, Y., and Wang, T.: Heterogeneous $\mathrm{N}_{2} \mathrm{O}_{5}$ uptake coefficient and production yield of $\mathrm{ClNO}_{2}$ in polluted northern China: roles of aerosol water content and chemical composition, Atmos. Chem. Phys., 18, 1315513171, https://doi.org/10.5194/acp-18-13155-2018, 2018.

Thornton, J. A. and Abbatt, J. P. D.: $\mathrm{N}_{2} \mathrm{O}_{5}$ reaction on submicron sea salt aerosol: Kinetics, products, and the effect of surface active organics, J. Phys. Chem. A, 109, 10004-10012, https://doi.org/10.1021/jp054183t, 2005.

Thornton, J. A., Braban, C. F., and Abbatt, J. P. D.: $\mathrm{N}_{2} \mathrm{O}_{5}$ hydrolysis on sub-micron organic aerosols: the effect of relative humidity, particle phase, and particle size, Phys. Chem. Chem. Phys., 5, 4593-4603, https://doi.org/10.1039/B307498F, 2003.

Thornton, J. A., Kercher, J. P., Riedel, T. P., Wagner, N. L., Cozic, J., Holloway, J. S., Dube, W. P., Wolfe, G. M., Quinn, P. K., Middlebrook, A. M., Alexander, B., and Brown, S. S.: A large atomic chlorine source inferred from midcontinental reactive nitrogen chemistry, Nature, 464, 271-274, https://doi.org/10.1038/nature08905, 2010.

U.S. Census Bureau: Quickfacts, available at: https://www.census. gov/quickfacts/, last access: March 2018.

Utah Department of Environmental Quality: Serious Area $\mathrm{PM}_{2.5}$ State Implementaion Plan Development, available at: https: //deq.utah.gov/air-quality/pm-2-5-serious-sips-2017-2019, last access: March 2019.

Utah Division of Air Quality: Utah State Implementation: Plan Control Measures for Area and Point Sources, Fine Particulate Matter, $\mathrm{PM}_{2.5}$ SIP for the Logan, UT Nonattainment Area, https:// 
deq.utah.gov/air-quality/pm2-5-moderate-sips-2009-2014 (last access: March 2019), 2014a.

Utah Division of Air Quality: Utah State Implementation: Plan Control Measures for Area and Point Sources, Fine Particulate Matter, $\mathrm{PM}_{2.5}$ SIP for the Provo, UT Nonattainment Area, available at: https://deq.utah.gov/air-quality/ pm2-5-moderate-sips-2009-2014 (last access: March 2019), 2014b.

Utah Division of Air Quality: Utah State Implementation: Plan Control Measures for Area and Point Sources, Fine Particulate Matter, $\mathrm{PM}_{2.5}$ SIP for the Salt Lake City, UT Nonattainment Area, available at: https://deq.utah.gov/air-quality/ pm2-5-moderate-sips-2009-2014 (last access: March 2019), 2014c.

UWFPS Science Team: 2017 Utah Winter Fine Particulate Study Final Report, available at: https://documents.deq. utah.gov/air-quality/planning/technical-analysis/research/ northern-utah-airpollution/utah-winter-fine-particulate-study/ DAQ-2018-004037.pdf (last access: March 2019), 2018.

Vaughan, S., Canosa-Mas, C. E., Pfrang, C., Shallcross, D. E., Watson, L., and Wayne, R. P.: Kinetic studies of reactions of the nitrate radical $\left(\mathrm{NO}_{3}\right)$ with peroxy radicals $\left(\mathrm{RO}_{2}\right)$ : an indirect source of $\mathrm{OH}$ at night?, Phys. Chem. Chem. Phys., 8, 3749-3760, https://doi.org/10.1039/B605569A, 2006.

Wagner, N. L., Dubé, W. P., Washenfelder, R. A., Young, C. J., Pollack, I. B., Ryerson, T. B., and Brown, S. S.: Diode laser-based cavity ring-down instrument for $\mathrm{NO}_{3}, \mathrm{~N}_{2} \mathrm{O}_{5}, \mathrm{NO}$, $\mathrm{NO}_{2}$ and $\mathrm{O}_{3}$ from aircraft, Atmos. Meas. Tech., 4, 1227-1240, https://doi.org/10.5194/amt-4-1227-2011, 2011.

Wagner, N. L., Riedel, T. P., Roberts, J. M., Thornton, J. A., Angevine, W. M., Williams, E. J., Lerner, B. M., Vlasenko, A., Li, S. M., Dubé, W. P., Coffman, D. J., Bon, D. M., de Gouw, J. A., Kuster, W. C., Gilman, J. B., and Brown, S. S.: The sea breeze/land breeze circulation in Los Angeles and its influence on nitryl chloride production in this region, J. Geophys. Res.Atmos., 117, D00V24, https://doi.org/10.1029/2012JD017810, 2012.

Wagner, N. L., Riedel, T. P., Young, C. J., Bahreini, R., Brock, C. A., Dubé, W. P., Kim, S., Middlebrook, A. M., Öztürk, F., Roberts, J. M., Russo, R., Sive, B., Swarthout, R., Thornton, J. A., VandenBoer, T. C., Zhou, Y., and Brown, S. S.: $\mathrm{N}_{2} \mathrm{O}_{5}$ uptake coefficients and nocturnal $\mathrm{NO}_{2}$ removal rates determined from ambient wintertime measurements, J. Geophys. Res.-Atmos., 118, 9331-9350, https://doi.org/10.1002/jgrd.50653, 2013.

Wahner, A., Mentel, T. F., Sohn, M., and Stier, J.: Heterogeneous reaction of $\mathrm{N}_{2} \mathrm{O}_{5}$ on sodium nitrate aerosol, J. Geophys. Res.-Atmos., 103, 31103-31112, https://doi.org/10.1029/1998JD100022, 1998.

Wang, H., Lu, K., Chen, X., Zhu, Q., Wu, Z., Wu, Y., and Sun, K.: Fast particulate nitrate formation via $\mathrm{N}_{2} \mathrm{O}_{5}$ uptake aloft in winter in Beijing, Atmos. Chem. Phys., 18, 10483-10495, https://doi.org/10.5194/acp-18-10483-2018, 2018.

Wang, S.-Y., Gillies, R. R., Martin, R., Davies, R. E., and Booth, M. R.: Connecting Subseasonal Movements of the Winter Mean Ridge in Western North America to Inversion Climatology in Cache Valley, Utah, J. Appl. Meteorol. Clim., 51, 617-627, https://doi.org/10.1175/JAMC-D-11-0101.1, 2012.

Wang, X., Wang, H., Xue, L., Wang, T., Wang, L., Gu, R., Wang, W., Tham, Y. J., Wang, Z., Yang, L., Chen, J., and Wang,
W.: Observations of $\mathrm{N}_{2} \mathrm{O}_{5}$ and $\mathrm{ClNO}_{2}$ at a polluted urban surface site in North China: High $\mathrm{N}_{2} \mathrm{O}_{5}$ uptake coefficients and low $\mathrm{ClNO}_{2}$ product yields, Atmos. Environ., 156, 125-134, https://doi.org/10.1016/j.atmosenv.2017.02.035, 2017a.

Wang, Z., Wang, W., Tham, Y. J., Li, Q., Wang, H., Wen, L., Wang, X., and Wang, T.: Fast heterogeneous $\mathrm{N}_{2} \mathrm{O}_{5}$ uptake and $\mathrm{ClNO}_{2}$ production in power plant and industrial plumes observed in the nocturnal residual layer over the North China Plain, Atmos. Chem. Phys., 17, 12361-12378, https://doi.org/10.5194/acp-1712361-2017, $2017 \mathrm{~b}$.

Washenfelder, R. A., Wagner, N. L., Dube, W. P., and Brown, S. S.: Measurement of atmospheric ozone by cavity ringdown spectroscopy, Environ. Sci. Technol., 45, 2938-2944, https://doi.org/10.1021/es103340u, 2011.

Watson, J. G. and Chow, J. C.: A wintertime $\mathrm{PM}_{2.5}$ episode at the Fresno, CA, supersite, Atmos. Environ., 36, 465-475, https://doi.org/10.1016/S1352-2310(01)00309-0, 2002.

Wexler, A. S. and Clegg, S. L.: Atmospheric aerosol models for systems including the ions $\mathrm{H}^{+}, \mathrm{NH}_{4}^{+}, \mathrm{Na}^{+}, \mathrm{SO}_{4}^{2-}, \mathrm{NO}_{3}^{-}, \mathrm{Cl}^{-}$, $\mathrm{Br}^{-}$, and $\mathrm{H}_{2} \mathrm{O}$, J. Geophys. Res.-Atmos., 107, ACH 14-11-ACH 14-14, https://doi.org/10.1029/2001JD000451, 2002.

Whiteman, C. D., Hoch, S. W., Horel, J. D., and Charland, A.: Relationship between particulate air pollution and meteorological variables in Utah's Salt Lake Valley, Atmos. Environ., 94, 742753, https://doi.org/10.1016/j.atmosenv.2014.06.012, 2014.

Wild, R. J., Edwards, P. M., Dube, W. P., Baumann, K., Edgerton, E. S., Quinn, P. K., Roberts, J. M., Rollins, A. W., Veres, P. R., Warneke, C., Williams, E. J., Yuan, B., and Brown, S. S.: A measurement of total reactive nitrogen, $\mathrm{NO}_{y}$, together with $\mathrm{NO}_{2}$, $\mathrm{NO}$, and $\mathrm{O}_{3}$ via cavity ring-down spectroscopy, Environ. Sci. Technol., 48, 9609-9615, https://doi.org/10.1021/es501896w, 2014.

Womack, C. C., McDuffie, E. E., Edwards, P. M., Bares, R., de Gouw, J. A., Docherty, K. S., Dube, W. P., Fibiger, D. L., Franchin, A., Gilman, J. B., Goldberger, L., Lee, B. H., Lin, J. C., Long, R., Middlebrook, A. M., Millet, D. B., Moravek, A., Murphy, J. G., Quinn, P. K., Riedel, T. P., Roberts, J. M., Thornton, J. A., Valin, L. C., Veres, P. R., Whitehill, A. R., Wild, R. J., Warneke, C., Yuan, B., Baasandorj, M., and Brown, S. S.: An odd oxygen framework for wintertime ammonium nitrate aerosol pollution in urban areas: $\mathrm{NO}_{x}$ and VOC control as mitigation strategies, Geophys. Res. Lett., 46, 4971-4979, https://doi.org/10.1029/2019GL082028, 2019.

Wood, E. C., Bertram, T. H., Wooldridge, P. J., and Cohen, R. C.: Measurements of $\mathrm{N}_{2} \mathrm{O}_{5}, \mathrm{NO}_{2}$, and $\mathrm{O}_{3}$ east of the San Francisco Bay, Atmos. Chem. Phys., 5, 483-491, https://doi.org/10.5194/acp-5-483-2005, 2005.

Zhang, L., Jacob, D. J., Knipping, E. M., Kumar, N., Munger, J. W., Carouge, C. C., van Donkelaar, A., Wang, Y. X., and Chen, D.: Nitrogen deposition to the United States: distribution, sources, and processes, Atmos. Chem. Phys., 12, 4539-4554, https://doi.org/10.5194/acp-12-4539-2012, 2012. 